\title{
Sudanian elements in the flora of Israel
}

A. Shmida and J.A. Aronson

\section{6}

Annals Missouri Botanical Garden

$$
\text { 73: } 1-28
$$




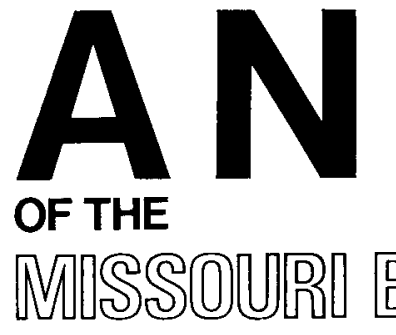

VOLUME 73
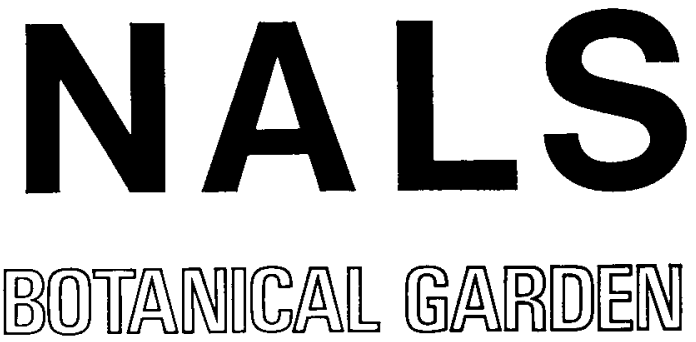

GARD促

\title{
SUDANIAN ELEMENTS IN THE FLORA OF ISRAEL ${ }^{1}$
}

\author{
A. Shmida ${ }^{2}$ ANd J. A. Aronson ${ }^{3}$
}

\begin{abstract}
In the Dead Sea Rift Valley of Israel, a northern tongue of penetration of Sudanian elements exists that has traditionally been regarded as composed of Miocene relicts. We postulate that most of these elements have penetrated the area since the end of the Pleistocene. The principal habitats harboring Sudanian elements in Israel are described, including the pseudo-savanna in wadi beds, cliffs and rock formation, oases and in the Dead Sea Rift as well as a variety of secondary habitats outside the Rift. In addition, a statistical analysis of the 116 species in the flora of Israel considered to be Sudanian elements is presented, covering growth form, phytogeographic distribution, dispersal mechanisms, and degree of endemism. Special attention is given to the arboreal elements, including 49 species of trees, shrubs, and perennial vines. A comparison is made between the habitats of these species in East Africa and in Israel: significant habitat shifts were found in some cases. Although paleo-macrofossils are almost non-existent in the area, other evidence, such as low degree of endemism, disjunctiveness, and adaptations to aridity and long-distance dispersal indicate that the great majority of the Sudanian elements in the Dead Sea Rift are of recent origin. The relationships between the typical evergreen Mediterranean elements with paleotropical origins and the extant Sudanian elements in Israel are discussed.
\end{abstract}

Within the portion of the Syrian-African Rift lying between the Red Sea to the south and the watershed of the Jordan River in the Golan Heights, a large number of Sudanian elements, plants as well as animals, are found considerably farther north than anywhere else in their distribution range and in many cases growing under ecological conditions quite different from their norm. In addition, a handful of Sudanian species also occur in the low-lying coastal plain of Israel, almost entirely cut off from the Dead Sea Rift Valley and the bulk of the Sudanian region proper (Fig. 1). Climatic and geological conditions in the Dead Sea Rift Valley explain in part the pres-

\footnotetext{
${ }^{1}$ A. Shmida wishes to express his considerable debt of gratitude to the late Prof. M. Zohary who introduced him (and dozens of other students) to the intricacies and unique attributes of the Israeli flora. We thank G. E. Wickens who reviewed the manuscript with meticulous care, helped gather information for some of the distribution maps, and made valuable suggestions for improvement of the text. J. B. Gillett and P. Quézel also kindly reviewed the manuscript and provided stimulating comments and suggestions. Our thanks also go to Sandy Greenberg, Seemah Shemesh, and Marion Milner who provided computer and typing assistance, to Nancy $\mathbf{R}$. Morin and Dr. Marjorie Tiefert for patient and professional editorial guidance, and to Miri Shmida who drew the figures. The assistance of J. Dransfield in preparing Figure 5 is gratefully acknowledged. Any errors or inaccuracies therein are entirely the responsibility of the authors. Finally we thank the numerous guides of the Israeli Society for the Protection of Nature who helped us locate some of the rare and little-known populations of Sudanian plants in Israel. We gratefully acknowledge financial assistance received during the course of this research from the Bath-sheva de Rothschild Fund to A. Shmida and the Clifford M. Hardin Fund of the Fund for Higher Education to J. A. Aronson.

${ }^{2}$ Department of Botany, The Hebrew University of Jerusalem, Jerusalem, Israel.

${ }^{3}$ Rudolf and Rhoda Boyko Institute for Agriculture and Applied Biology, Institutes for Applied Research, Ben-Gurion University of the Negev, P.O. Box 1025, Beer-Sheva 84110, Israel.
}

ANN. Missouri Bot. GARD. 73: 1-28. 1986. 


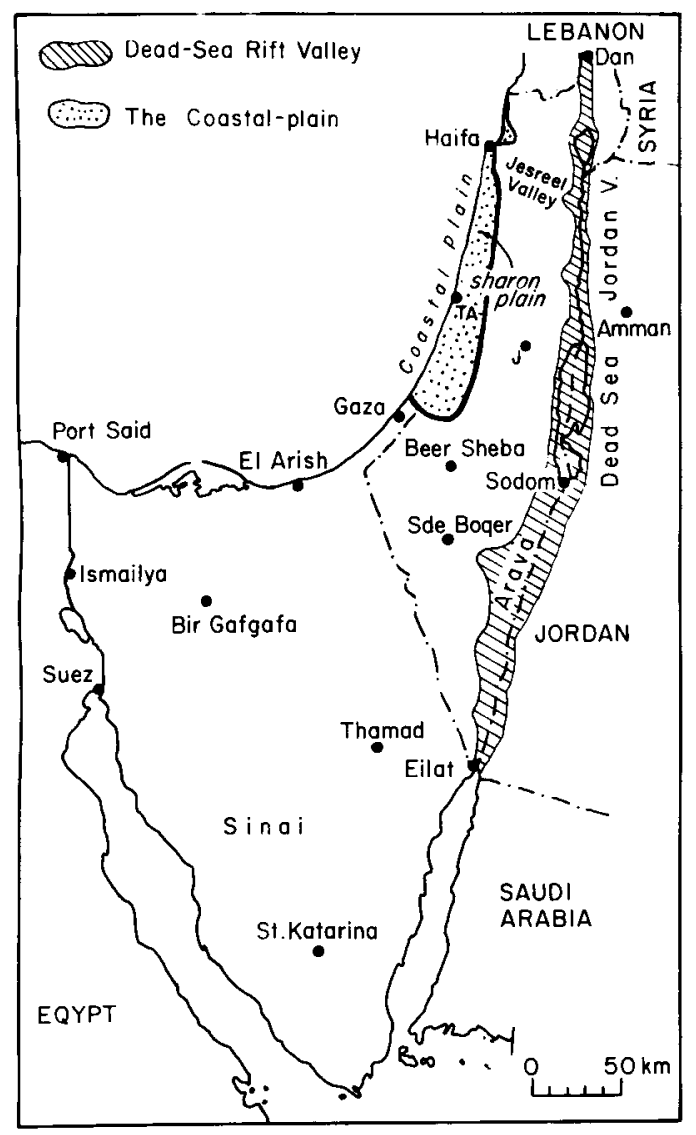

FIGURE 1. General geographical aspect of the study area with the main districts harboring Sudanian elements.

ence of Sudanian species so far north, but several questions remain concerning the present ecological adaptations and distribution patterns of the Sudanian elements in Israel. The most intriguing of these is simply: how and when did these species, whose principal distribution is in subtropical Africa and similar regions in Arabia and the Thar Desert of India and West Pakistan reach Israel particularly in the Dead Sea Rift Valley?

Only two papers relating directly to the Sudanian floristic elements in Israel can be found in the literature. One is Eig's work, in which he cites about 170 species of plants from the Dead Sea Rift Valley, of which more than $30 \%$ are Sudanian (Eig, 1931-1932). The second paper (Gruenberg-Fertig, 1954) is a renewed and detailed phytogeographical analysis of the Sudanian species in Palestine with particular emphasis on the affinities of those elements to the Eritreo-
Arabian and West-Sudanian subregions of Engler (1879-1882) and others.

Since the publication of Eig's and GruenbergFertig's works, our knowledge of the vegetation of Israel and its neighboring areas has increased greatly. This is due mainly to the publication of new floras of Israel (Zohary \& Feinbrun-Dothan 1966-1974; Feinbrun-Dothan, 1978, 1985), Egypt (Täckholm, 1974), the Sahara (Ozenda, 1977), the Thar Desert (Bhandari, 1978), and others (e.g., Wickens, 1977; Lind \& Morrison, 1974; Danin, 1983). We have to date recorded more than 800 species of plants growing in the Dead Sea Rift Valley, of which $14.5 \%$ can be considered Sudanian elements. More ecological information concerning the Sudanian elements in Israel outside the Dead Sea Rift Valley has also been collected, and additional information on the details of the ranges of many Sudanian species has been amassed. Consequently, the conclusions of Eig, Zohary, Gruenberg-Fertig, and others on the age and origin of the Sudanian elements in Israel should be reconsidered.

The dominant view of this question, as presented by Zohary (1973), Tchernov (1968), and others has held that the Sudanian elements in Israel, both within the Dead Sea Rift Valley and along the coastal plain, are Miocene relicts surviving in specialized habitats from an earlier, warmer, and wetter period when tropical vegetation occurred as far north as central Europe.

The opposing view, held by Tristram (1884), Hart (1891), and Bodenheimer (1935), argues that the Sudanian elements in Israel are recent and arrived in Israel in waves during the warm intervals that occurred during the Pleistocene, i.e., during the last million years. Galil (1972) revived this theory and even went so far as to suggest that most of the Sudanian plants occurring in Israel today are the result of the most recent penetration that took place in the hyperthermic period about 4,000 to 8,000 years ago.

The purpose of this paper is to enlarge on and analyze the findings related to the Sudanian elements in Israel and to attempt to resolve the issue of the relative age of the extant Sudanian vegetation in Israel. Since fossil records relevant to this discussion are essentially non-existent, we will attempt to apply ecological theory and phytogeographical analysis to elucidate the issue. Furthermore, we can compare the local situation with that of nearby regions that have already been analyzed, e.g., the Saharo-North African Region studied by Monod (1957), Ozenda (1977), 
Quézel $(1958,1965,1978)$, and others as well as recent general studies of the vegetation of Africa, such as those by Knapp (1973) and White (1976, 1983), and of nearby regions including Iran (Hedge \& Wendlebro, 1978) and Arabia (Mandaville, 1984).

\section{The ENVIRONMENT-GeOMORPHOLOGY and Climate}

The Dead Sea Rift Valley (Fig. 1), which is subdivided into the Jordan Valley and the Arava Valley, is part of the northern section of the Syrian-African Rift that extends from northern Syria southwards through the Red Sea, terminating in East Africa (Garfunkel, 1970, Freund \& Garfunkel, 1978). This rift is a relatively new feature that has been slowly widening since OligoceneMiocene times (Freund 1965, Freund et al., 1970). During this period, the Arabian Peninsula and Jordan have moved at least $40 \mathrm{~km}$ northwards with respect to Egypt, the Sinai, and Israel (Freund et al., 1968). Since the Pliocene, this movement has led to the concomitant formation of a deep rift so that the rivers that once drained from Transjordan into the Mediterranean Sea now drain into the Dead Sea Rift from Dan in the north to the central Arava in the south.

The Dead Sea Rift is defined by two large fault systems running in a north-south direction that border it on the west and east. These systems have caused the formation of large cliffs and steep inclines on either side of a deep depression (Garfunkel \& Horowitz, 1966; Neev \& Emory, 1967). Climatically, this depression constitutes a rainshadow desert, the intensity of which is determined by the abrupt difference in altitude (ca. $100 \mathrm{~m}$ ) between the valley floor and the mountains to the west, beyond which most of the rain fronts originate.

Rainfall throughout the Middle East decreases from north to south, and the precipitation gradient in the area under discussion decreases from $600 \mathrm{~mm}$ annually in the Dan area in the north of Israel to $27 \mathrm{~mm}$ in the Eilat area in the south (Anonymous, 1970). In keeping with this, distinct changes in vegetation zones are observed, from the extreme xeric vegetation in the Arava (south) through the steppe vegetation in the Jericho-Beit Shean area (central) to the Mediterranean vegetation in the Hula Valley area (north) (Fig. 2). The more intense the rain-shadow formed in the Dead Sea Rift Valley the further north the xeric vegetation zones penetrate. Accordingly,

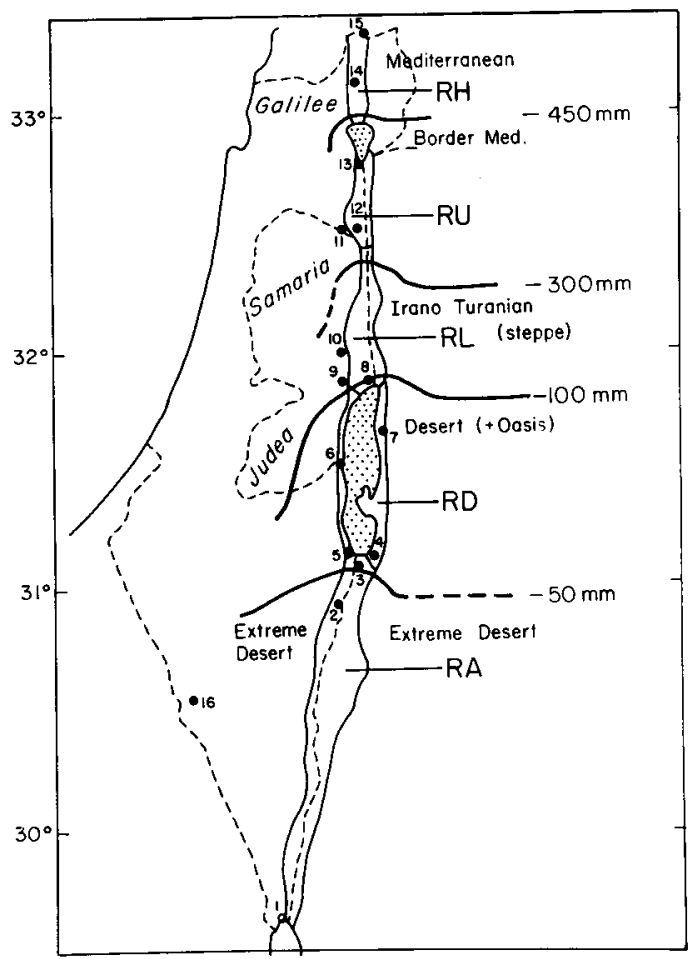

FIGURE 2. Dominant phytogeographical regions within the Dead Sea Rift Valley (modified after Zohary, 1973) and mean annual rainfall isohytes.

xerophytic desert vegetation in the rain-shadow area of the Judean Desert penetrates as far north as Wadi Auja, and Irano-Turanian steppe vegetation penetrates up to the Mt. Gilboa area.

Because the flora and fauna inhabiting the slopes descending to the Dead Sea Rift Valley have also been influenced by the sharp depression of the Syrian-African Rift, these slopes are considered part of the Dead Sea Rift Valley for this paper. Like other typical geomorphological depressions, the Dead Sea Rift includes wide alluvial valleys, some draining to the Red Sea and some with underground drainage systems in which salt marshes and saline springs have formed. Large fault and contact springs have led to the formation of extensive oases that are characteristic of the fault escarpment area. Thus, four habitat types exist in the Dead Sea Rift that can support Sudanian floristic (and faunal) elements, as will be discussed in detail below. The great majority of Sudanian species occurring in Israel are found in one or more of these habitats.

Outside the Dead Sea Rift, a smaller number of Sudanian elements are found in a variety of 
habitats throughout the low-lying plains and valleys of the coastal and inland regions. The two important outlying districts that support Sudanian elements, i.e., the Dead Sea Rift and the coastal plain, are separated by the mountainous regions of Judea, Samaria, and the Galilee (Fig. 2). However, a sparse transitional zone does exist between the two in southern Israel from the Arava Valley through the northern Negev to the coastal plain. Moving north and west along this transitional zone, the Sudanian elements are increasingly restricted to distinctly thermic habitats such as southern exposures. The abundance of these elements decreases along the zone with the exception of the hydrophilic species, which are most abundant in the coastal plain.

\section{The Paleogeography and Paleoecology of the Dead Sea Rift Valley}

During the Eocene a tropical climate prevailed in the latitudinal subtropical belt of the world (Zohary, 1973; Axelrod \& Raven, 1978). As a result, tropical vegetation dominated in the Mediterranean basin and as far north as central Europe and England as indicated by fossilized leaves and fruits of tropical trees found in those areas. These fossils belong to the paleophytogeographical Laurosilvia geoflora (Takhtajan, 1969; Zohary, 1973). The tropical forests of southeast Asia are the largest and most representative areas in which elements of this vegetation have survived today (Zohary, pers. comm.; Thorne, pers. comm.).

Great changes took place during the Miocene (Axelrod, 1975). Along with the Alpine orogenesis, desertification and disintegration occurred in the subtropical belt, and the tropical vegetation retreated towards the equator. At this time, the Tethys Sea, which had covered large areas of the Middle East and central Asia, shrank and was replaced by large steppe areas (Tchernov, 1975). The process of desertification continued throughout the Pliocene, which was, however, a much colder period than the Miocene. The principal development of the steppe flora of central Asia (including many Chenopodiaceae, Artemisia, and other typical Irano-Turanian representatives) is believed to have occurred then. This flora penetrated to north Africa through the Middle East and reached the coast of the Spanish Sahara. During the Pliocene a branch of the Mediterranean Sea penetrated through the Jezreel Valley of Israel and formed a saline lake in the central and upper Jordan Valley (Horowitz, 1979).

During the Pleistocene, extreme fluctuations between rainy and dry periods occurred in the subtropical belt. During the last cycle it was colder and rainier in Israel than at present by some $3-4^{\circ} \mathrm{C}$ in temperature and an undetermined amount of less average annual precipitation (Horowitz, 1979).

Following the end of the Wuram period in the Middle East about 17,000 years ago (Bar Yosef, 1975), a trend towards warmer, drier conditions began, reaching present levels by about 8000 B.C. Since then, during the Holocene, very few major climatic changes are believed to have taken place (Horowitz, 1979). Around 6000 B.C., a brief hyperthermic period occurred and approximately 4000 B.C., a colder one (the Atlantic period) (Nir \& Bar Yosef, 1976).

Until the Pliocene, the Dead Sea Rift Valley was a shallow depression that did not interfere with the flow of rivers from Transjordan to the Mediterranean Sea (Garfunkel \& Horowitz, 1966). Since then, the drastic deepening of the Dead Sea Rift by faults on both sides resulted in the formation of the Judean Desert area, a rainshadow desert, and the thermophilic, arid-tropical conditions of the Dead Sea Rift Valley, particularly around the Dead Sea (Neev \& Emory, 1967).

This historical geographical description has been derived from geological and geomorphological evidence and not from direct botanical evidence. Israel is extremely poor in plant fossils: the only two finds in this field after the Mesozoic era are leaves of tropical species found in Miocene formation in the Yemin Plain and Hatzeva (Lorch, 1966). This suggests that the climate in that period in the Negev and Dead Sea Rift was more tropical. Zoological evidence from the Miocene-Pliocene period is also rather poor but increases from the end of the Pliocene to the present (Tchernov, pers. comm.).

\section{Definition and Delineation of The Sudanian Phytogeographical Region}

The Sudanian phytogeographical region constitutes one of the most problematic in the Old World in terms of classification and delineation. Grisebach (1884) classified all of tropical Africa as a "Sudanian" zone. Subsequently, throughout the last century, there have been several attempts to further delineate the arid and semi-arid re- 


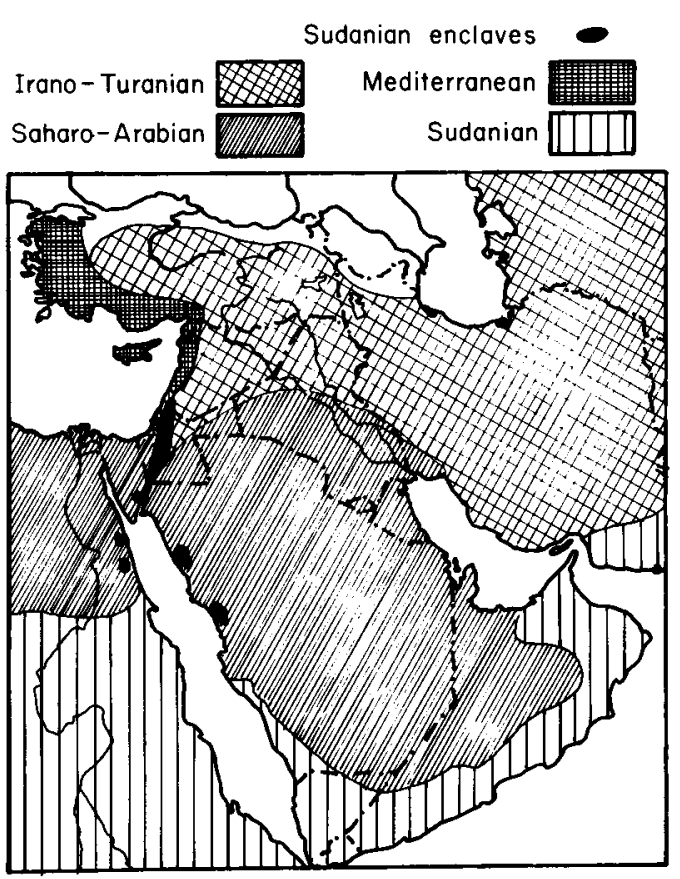

FIGURE 3. Phytogeographical regions relevant to the study area (modified after Zohary, 1973). Note the striking penetration of the Sudanian elements northward along the Dead Sea Rift Valley.

gions in Africa and relevant regions of the Middle East and the Indian subcontinent (Engler \& Drude, 1896; Chevalier, 1938; Eig, 1938; Good, 1964; Meyer-Homji, 1965; Burtt, 1971; Zohary, 1973; Werger, 1973; Wickens, 1977; Werger \& Coetzee, 1978; Hedge \& Wendlebro, 1978; Walter, 1979; White, 1967, 1983; Mandaville, 1984).

Eig (1938), who was the first to study in detail the phytogeographical regions of and relevant to the Middle East, defined a "Sudano-Deccanian region" that included a relatively narrow belt in west Africa and a much broader portion of east and northeast Africa, thence across the Red Sea, around coastal Arabia, and eastward to the Deccan Plateau in central India. Concomitantly, he combined the region of Sind (western Pakistan), northwest India (principally Rajasthan), and parts of Baluchisthan and southern Iran with the hyper-arid Sahara Desert that lies roughly in the same latitudes. This broad region he called "Saharo-Sindian."

Zohary $(1945,1963,1973)$ revised Eig's scheme by combining the "Sindian" region with the African and Arabian parts of Eig's "Sudano-Deccanian region," while including the Deccan Peninsula in the Saharo-Arabian portion of Eig's

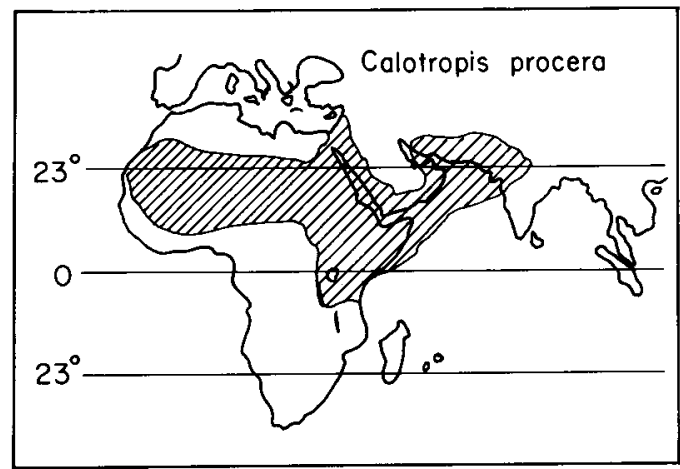

Figure 4. Distribution map of Calotropis procera that represents a typical Sudanian distribution (sensu Zohary, 1973).

"Saharo-Sindian region." For simplicity, Zohary called the results of this switch the "Sudanian" and "Saharo-Arabian" phytogeographical regions, respectively (Figs. 3, 4).

Gruenberg-Fertig (1954) and Monod (1957) also questioned the affinity between the Deccan flora and that of the Saharan and Arabian regions. Both of these authors commented on Eig's own recognition of the relative individuality of the flora of the semi-arid Deccan Peninsula as compared with the rest of his "Sudano-Deccanian region." In 1965, Meyer-Homji categorically rejected the validity of a "Sudano-Deccanian region" and proposed instead a "Sudano-Rajasthanian region," because "it is the semi-arid Rajasthan which offers closer analogies with the Sudan region, by consideration of the bio-climatic conditions and the ombrothermic diagrams." More significantly from our point of view, Meyer-Homji (1965) showed that "the strength of the so-called Sudano-Deccanian element in the entire southern semi-arid zone [of India], including the Deccan, is only $2.6 \%$," while in the northern semi-arid zone (i.e., Rajasthan and adjacent parts of Gujerat and Punjab), "it is two times higher (5.6\%)."

Unfortunately, in the same paper Meyer-Homji (1965) supported the use of Eig's term "SaharoSindian" to combine the Saharo-Arabia region with Sind sensu stricto, that is, the Indus River Valley to the west of Rajasthan. Thus, additional confusion was created concerning the division of the macro-regions in question.

Eig's term "Saharo-Sindian" was again revived in a recent paper by Hedge and Wendlebro (1978) dealing with southern Iran. These authors argued moreover, that this term should also be 


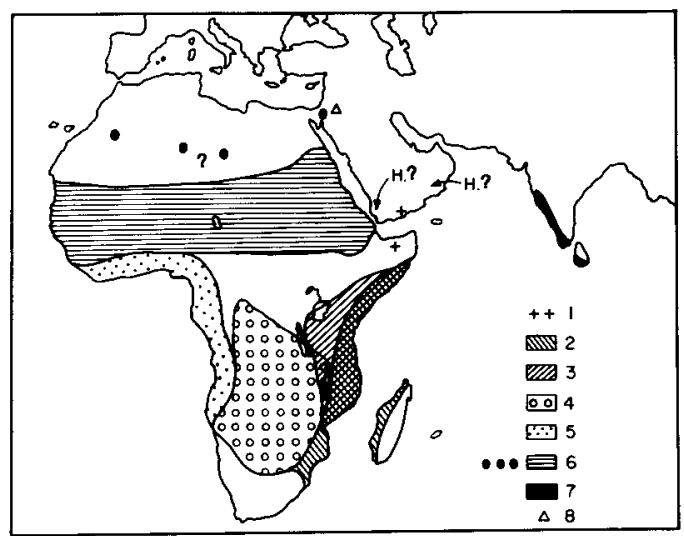

FIGURE 5. The genus Hyphaene, which represents a Sudanian-Zambesian distribution (sensu Werger, 1978). Key: $1=H$. reptans, $2=H$. coriacea, $3=H$. compressa, $4=H$. petersiana, $5=H$. guineensis, $6=$ $H$. thebaica, $7=H$. dichotoma, $8=H$. sinaitica (the only record; the distinction of this taxon from $H$. the baica is not recognized by Feinbrun-Dothan, 1985).

used to describe the portion of southern Iran described by Zohary (1973) as "Sudanian." Based on their observations in southern Iran, Hedge and Wendlebro cast doubt on the validity of describing any of the species in southern Iran as "Sudanian elements." Instead, they maintained that most of the prominent species grouped by Zohary, Eig, and others under the rubric of "Sudanian elements" could be better classified as "east-west tropical African/Arabian" elements (Hedge \& Wendlebro, 1978: 456). "The species of this element," they wrote, "are very widely dispersed with no clear pattern other than being widely dispersed in subtropical and tropical parts of the Old World. In Iran, they grow quite intermixed with the species of the north African/ Arabian element," which is the name they proposed in place of Zohary's "Saharo-Arabian" elements.

In striking contrast, Mandaville (1984) recently offered strong support for Zohary's phytogeographic terminology, including the concept of a "Sudanian" group of elements. He even went so far as to propose an extensive enlargement of the territory delineated by Zohary as "Sudanian" in Arabia. According to Mandaville (1984), not just the coastal regions, but nearly two-thirds of the Arabian Peninsula should be classified as "Sudanian," at the expense of the "Saharo-Arabian" territory as defined by Zohary (1973).

We believe that outside of Africa, and most certainly on the temperate fringes of the distri- bution of the basically tropical elements under discussion, it is not at all surprising to find "Sudanian" elements intermingling with the numerically more significant eremaic Saharo-Arabian and/or other local elements. In Israel the same situation is found, as will be described in detail below.

Within Africa itself, White (1983) has confirmed the existence of a "Sudanian regional center of endemism," one of only seven such centers that he recognizes for the entire continent (he points out that it is the "least unambiguously defined" of the centers of endemism by his criteria). By contrast, the Sahelian region is treated by White as one of a number of regional transitional zones, "showing gradual replacement of one flora with another that is little complicated by endemism" (White, 1983: 43). We will follow White in this matter, rather than Chevalier (1938) and Greenway (1970) who recognized a "Sahelien zone" per se, or Le Houerou and Popov (1981) among others who speak of a "SudanoSahelien zone."

Burtt (1971) has emphasized the strong floristic similarity between the semidesert floras of the Sudanian region (sensu Zohary, 1973) and those of the southern half of Africa. Accordingly, Burtt recognized an amalgamated "Sudano-Zambesian phytogeographical region," which was supported and discussed in more detail by Werger (1973) and Werger and Coetzee (1978) (see Fig. 5). It is worth noting that this concept corresponds with Engler's original scheme of 18791882. We realize that strong affinities exist between the semidesert and savanna floras of the southern and northern halves of Africa and therefore acknowledge the validity of Burtt's terminology. We argue, however, that given the current sketchy state of knowledge, phytogeographic delineation in Africa is still largely a matter of perspective and individual opinion. Until a careful computerized analysis can be undertaken of the floristic and genetic components of the various regional floras under discussion, no hard and fast nomenclature can be agreed upon. In the meantime, we choose to follow Zohary's and White's general concept (if not all specific details) of the Sudanian phytogeographical region. We choose this course not only for practical reasons but also to provide historical continuity.

In contrast to the lack of agreement on the delineation of the phytogeographical regions under discussion, there is overall agreement concerning the zoogeographic regions (Bodenhei- 
mer, 1935; Udvardy, 1969). Two separate zoogeographical regions are consistently distinguished in the Old World: the Ethiopian region in Africa and the Oriental region in Asia.

It is important to emphasize here the striking difference between the phyto- and the zoogeographic regions as defined by biogeographers concerned with the Old World, for it reflects a major distinction between the macro-distribution of animals and plants in the area. Whereas a relatively strong line of demarcation apparently exists between the respective faunas of the African and Asian continents, no such division exists between the two floras.

Above all, we wish to emphasize that our objective here is not to delineate a Sudanian phytogeographic region in Israel, in our view, such an effort is unjustified. Instead we are concerned with the occurrence, distribution, and ecological behavior of the relatively limited number of Sudanian elements that reach our study area. By the same token, we have no desire to enter into taxonomic disputes. With very few exceptions, we follow the taxonomy given in the "Flora Palestina" and other published floras (Zohary \& Feinbrun-Dothan, 1966-1974; Feinbrun-Dothan, 1978, 1985) even where it is clear that further taxonomic revision is required.

\section{TyPiCAL AND Key Determinants OF THE SUDANIAN ELEMENTS}

The Sudanian zone as a whole is typified by plants of tropical origin that have acquired one or more adaptations to relatively hot and arid conditions, yet retain higher demands for moisture than true desert species. The characteristic vegetation type is the savanna-low, open forests of small trees and large shrubs with perennial grasses dominating the open spaces between them (Shmida, 1982). The trees are typically multistemmed with sparse, open canopies. Many of them are spiny, with small compound, xeromorphic leaves. Some are evergreen (Balanites, Maerua, Boscia, Salvadora, and some Ziziphus species) and some are drought-deciduous (e.g., Acacia, Albizia, and Commiphora (species). Many are characterized by a reduced leaf area, with green stems assuming some of the photosynthetic function. In retamoid (broom-like) shrubs this adaptation is most prominent-the plants being leafless throughout most of the year while the stems become the primary photosynthetic organs. Some examples of this group are
Moringa peregrina, Capparis decidua, Leptadenia pyrotechnica, Ochradenus baccatus, and Periploca aphylla.

Many of the trees have an umbrella shape, which is most striking in Acacia-the dominant genus of the Sudanian savannas. Xerophytic vines are occasionally found climbing on the savanna trees (e.g., Cocculus pendulus, Commicarpus and Boerhavia spp., asclepiad vines such as Oxystelma esculenta as well as various perennial cucurbits).

The Sudanian flora in the Dead Sea Rift is typical in its arboreal elements but unusual in lacking a continuous grass cover between the trees. Some Sudanian grasses do occur there-species of Pennisetum, Cenchrus, Cymbopogon, Enneapogon, and others. But the overall aspect of the vegetation type in the Dead Sea Rift is best described as a pseudo-savanna, owing to the scarcity of perennial grasses. Moreover, a wide range of non-Sudanian, desert chamaephytes belonging to the Saharo-Arabian phytogeographical region intermingle with the Sudanian elements, creating a kind of bi-regional patchwork or mosaic. In the hammadas or regs and other portions of the Dead Sea Rift where no suitable habitats occur for Sudanian elements, the Saharo-Arabian elements dominate (Zohary, 1962). The same pattern is apparently also found in west and north Africa (Quézel, 1965, 1978).

\section{Statistical Analysis of the Sudanian \\ FLORA IN ISRAEL IN RELATION TO GROWTH-FORMS, TAXONOMY, AND Global Distribution}

A statistical analysis of the flora of Israel (according to Zohary \& Feinbrun-Dothan 19661974; Feinbrun-Dothan, 1978, 1985, pers. comm.) shows that 157 plant species, out of a total of 2,173 (i.e., $7.2 \%$ ), belong at least partially to the Sudanian phytogeographic region. Of these, 116 species, or $68.8 \%$ of the subtotal, are considered to be predominantly Sudanian in distribution, sensu Zohary (1973) (Table 1). This represents about $5.3 \%$ of the total Israeli flora; it is on this group of 116 species that all further statistical analysis will be based.

Most of the species accepted here as Sudanian show either a straightforward Sudanian distribution or chorotype $(55.1 \%)$ or a bi-regional Sudanian-Saharo-Arabian chorotype $[10.3 \%$ (SU$\mathrm{SA})+18.1 \%(\mathrm{SA}-\mathrm{SU})=28.4 \%]$. In both of these 
TABLE 1. Phytogeographical analysis of the Sudanian elements in the flora of Israel and their growth forms [data from the "Flora Palestina" (Zohary \& Feinbrun-Dothan, 1966-1974; Feinbrun-Dothan, 1978, 1985) with corrections].

\begin{tabular}{|c|c|c|c|c|c|c|c|c|c|c|}
\hline Chorotype $^{a}$ & $\underset{\text { ber }}{\text { Num- }}$ & $\begin{array}{l}\text { Per- } \\
\text { cent }\end{array}$ & Trees & Shrubs & $\begin{array}{c}\text { Cham- } \\
\text { ae- } \\
\text { phytes }\end{array}$ & $\begin{array}{l}\text { Hemi- } \\
\text { crypto- } \\
\text { phyte }\end{array}$ & $\begin{array}{l}\text { An- } \\
\text { nual }\end{array}$ & $\begin{array}{c}\text { An- } \\
\text { nual/ } \\
\text { Facul- } \\
\text { tative } \\
\text { Peren- } \\
\text { nial }\end{array}$ & Vine & $\begin{array}{c}\text { Para- } \\
\text { site }\end{array}$ \\
\hline Sudanian & 64 & 55.1 & $17.2^{b}$ & 18.7 & 31.3 & 6.2 & 14.1 & 3.1 & 7.8 & 1.6 \\
\hline Sudanian-Saharo-Arabian & 12 & 10.3 & 11.1 & 11.1 & 33.3 & 22.2 & 11.1 & - & 11.1 & - \\
\hline Sudanian-Tropical & 9 & 7.7 & - & 25.0 & 4.0 & 4.0 & 16.0 & 25.0 & - & - \\
\hline Sudanian-Mediterranean & 3 & 2.6 & 33.3 & - & - & - & 33.3 & 33.3 & - & - \\
\hline Sudanian-Irano-Turanian & 3 & 2.6 & 33.3 & 66.6 & - & - & - & - & - & - \\
\hline Pluriregional & 4 & 3.5 & - & - & - & 25.0 & 25.0 & 25.0 & - & 25.0 \\
\hline Saharo-Arabian-Sudanian & 21 & 18.1 & 19.1 & 4.8 & 33.3 & 19.1 & 9.5 & 14.3 & - & - \\
\hline Total & 116 & 100.0 & 15.5 & 16.4 & 26.7 & 11.2 & 15.5 & 7.7 & 5.2 & 1.7 \\
\hline
\end{tabular}

a Chorotype = distribution, sensu Zohary (1973).

b 17.2 here refers to the percent of species of a particular growth form within the total number of species within the chorotype group, e.g., 11 trees $/ 64$ Sudanian $=17.2 \%$.

groups, the high percentage of trees, shrubs, and chamaephytes is especially notable.

Of the eight families most abundant in Sudanian elements in the flora of Israel, five families show significantly higher importance than the reference (meaning a greater percentage contributed by the family in the total number of species in the Israeli flora; see Table 2). These are Chenopodiaceae $(5.2 \%$ versus $3.2 \%)$, Euphorbiaceae $(5.2 \%$ versus $1.6 \%)$, Zygophyllaceae ( $4.3 \%$ versus $0.9 \%)$, Asclepiadaceae $(6.9 \%$ versus $0.7 \%$ ), and Capparaceae ( $6 \%$ versus $0.4 \%$ ). The last four of these families have tropical diversity centers (Ozenda, 1977). The higher representation of the Chenopodiaceae in the Sudanian flora than in the reference is perhaps related to the large number of pluriregional chorotypes in this family.

The lower portion of Table 2 reveals the negligible representation of a few typically temperate families in the Sudanian flora of Israel. While the Rosaceae, Ranunculaceae, and Apiaceae have no Sudanian representatives in Israel whatsoever, the Brassicaceae contribute three Sudanian species, which account for $2.6 \%$ of the total Sudanian flora in Israel.

Although a total of $\mathbf{9 2}$ genera in $\mathbf{4 0}$ families are represented, very few genera show large numbers of species with predominantly Sudanian distribution. Only Acacia has four species in the group. Five genera have three species each: Commicarpus, Capparis, Cleome, Moretia, and Tamarix. Ten genera are bitypic and 76 are monotypic. Overall, the mean number of Sudanian species per genus among Sudanian elements in Israel is 1.30 , which is quite low relative to the mean number (3.05) of species per genus within the entire flora of Israel.

\section{Distribution and ECOLOGY OF SUDANIAN Elements IN The Dead Sea RIFt Valley}

The environmental conditions that support Sudanian vegetation in the heart of the Sudanian region in east Africa and the Thar Desert are high ambient temperatures during the growing season, a relatively warm, frost-free winter, and two rainy seasons. The rains come in spring and autumn, with total annual rainfall averaging between 250 and $500 \mathrm{~mm}$ (Walter, 1979; Zohary, 1973). In the west African region alternately called Sudanian or Sahelian, a single rainy season occurs in summer, with precipitation averaging 75 to 400 (to 500 ) $\mathrm{mm}$ per year (Wickens, pers. comm.).

The first mentioned determinant of the distribution of Sudanian elements-high year-round temperatures - is found in Israel primarily in the Dead Sea Rift Valley. Accordingly, assuming successful dispersal of diaspores from the Sudanian region to the Dead Sea Rift, or their preexistence there in the past, Sudanian elements should be found in those habitats in the Dead Sea area with moisture regimes similar to those of the main Sudanian region. However, such habitats are relatively very small and scattered. 
Moreover, they are specialized habitats that differ ecologically from the true savanna environments of the Sudanian region in Africa.

\section{PRINCIPAL HABITATS OF SUDANIAN ELEMENTS} IN THE DEAD SEA RIFT

(1) Pseudo-savanna in wadi beds and flood plains. In the large wadi beds of the Arava Valley, Acacia species ( $A$. tortilis and $A$. raddianasometimes described as $A$. tortilis subsp. raddiana) dominate the landscape, and a variety of xeric desert species are interspersed among them. We define pseudo-savanna as an association dominated by large savanna trees that can tap the deep year-round ground water available in the wadi beds, but which is virtually lacking the understory of drought-resistant perennial grasses typical of a true savanna. Instead most of the associated species are xeric desert shrubs and annuals such as Zilla spinosa, Moricandia nitens, Anabasis articulata, and Achillea fragrantissima, all of which belong to the Saharo-Arabian phytogeographic group. The non-arboreal Sudanian elements, as well as most of the shrubs and vines, have migrated up to the cliffs and rocky sites on either side of the Rift Valley. It is important to emphasize that these pseudo-savannas do not cover large areas as they do in Africa but are confined to relatively narrow water courses in flood plains. Zohary (1945) suggested the term "gallery forest" to describe this association; since this term has been extensively used to describe riparian vegetation on the border of the humid tropics (see Wickens, 1977: 30-31), we propose a new term-"Arterial Desert Savanna" for the pseudo-savanna described here. In essence, this term corresponds to the "savane désertique" of Quézel (1965).

(2) Cliff and rock formations. Small rock crevices, outcrops, and rocky slopes facing south and east, characterized by warm conditions and a relatively stable water regime, support numerous Sudanian elements, including small shrubs (e.g., Ephedra foliata), dwarf shrubs (Abutilon frutescens), and perennial grasses (e.g., Tetrapogon villosus). In addition, large cliff faces in the fault escarpment along either side of the Dead Sea Rift and scattered throughout the Negev and Sinai provide moist, thermic conditions that support many of the Sudanian species occurring in the area. Important examples are Capparis cartilaginea, Periploca aphylla, and Cocculus pendulus.
TABLE 2. Relative importance of species numbers within the important families of the Israeli flora and the Sudanian elements within them. ${ }^{\mathrm{a}}$

\begin{tabular}{|c|c|c|c|c|}
\hline \multirow[b]{2}{*}{ Family } & \multicolumn{2}{|c|}{$\begin{array}{c}\text { Species in } \\
\text { Israel with } \\
\text { Predominantly } \\
\text { Sudanian } \\
\text { Distribution }\end{array}$} & \multicolumn{2}{|c|}{$\begin{array}{c}\text { Total Species } \\
\text { in Israel }\end{array}$} \\
\hline & $\underset{\text { ber }}{\text { Num- }}$ & $\begin{array}{l}\text { Per- } \\
\text { cent }\end{array}$ & $\begin{array}{c}\text { Num- } \\
\text { ber }\end{array}$ & $\begin{array}{l}\text { Per- } \\
\text { cent }\end{array}$ \\
\hline Papilionaceae & 9 & 7.7 & 264 & 12.1 \\
\hline Compositae & 4 & 3.4 & 246 & 11.3 \\
\hline Gramineae & 9 & 7.7 & 208 & 9.6 \\
\hline Chenopodiaceae & 6 & 5.2 & 70 & 3.2 \\
\hline Euphorbiaceae & 6 & 5.2 & 34 & 1.6 \\
\hline Zygophyllaceae & 5 & 4.3 & 20 & 0.9 \\
\hline Asclepiadaceae & 8 & 6.9 & 15 & 0.7 \\
\hline Capparidaceae & 7 & 6.0 & 8 & 0.4 \\
\hline $\begin{array}{l}\text { Brassicaceae } \\
\text { (Temperate) }\end{array}$ & 3 & 2.6 & 115 & 5.3 \\
\hline $\begin{array}{l}\text { Apiaceae } \\
\text { (Temperate) }\end{array}$ & 0 & 0 & 93 & 4.3 \\
\hline $\begin{array}{c}\text { Rununculaceae } \\
\text { (Temperate) }\end{array}$ & 0 & 0 & 45 & 2.1 \\
\hline $\begin{array}{l}\text { Rosaceae } \\
\text { (Temperate) }\end{array}$ & 0 & 0 & 21 & 1.0 \\
\hline
\end{tabular}

a The two columns of the table do not total $100 \%$, because not all the families are included.

b The total number of species in Israel with a predominantly Sudanian distribution is 116 .

c The total number of species in the entire flora of Israel is 2,173 .

Some of these species are obligate chasmophytes and they (or vicarious species) grow only on cliffs even in the Sudanian region proper. Examples of these are Sonchus suberosus and Caralluma spp. Some species that occur only on rocky cliffs in the Dead Sea Rift, however, grow as scrambling climbers supported by Acacia and other trees on non-rocky ground in the east African savannas. The outstanding example is $\mathrm{Coc}$ culus pendulus; other examples are found in Ephedra and the Commicarpus/Boerhavia complex. In these cases, the habitat of the Sudanian plants has shifted in the more arid environment of the Dead Sea Rift so that their growth conditions, in terms of temperature and water, remain relatively unchanged.

However, for at least a few of the scandent species (e.g., Oxystelma alpini), the shift to rocky habitats also represents a shift in growth conditions. In such circumstances, we can say that a niche shift has taken place - a well-known zoological phenomenon (MacArthur, 1972) but one 


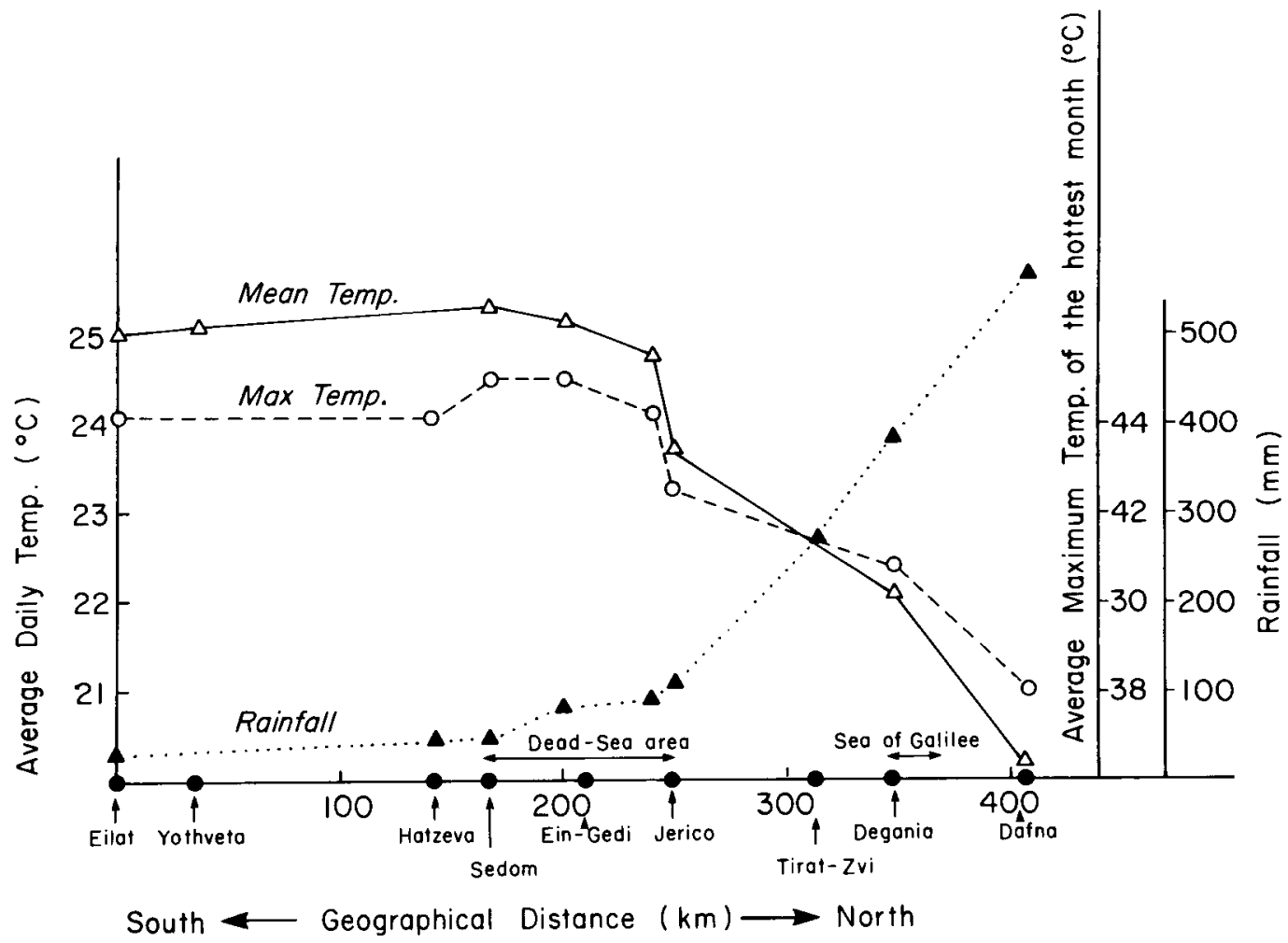

FIGURE 6. Mean annual rainfall and average daily temperature and average maximum temperature along the Dead Sea Rift axis.

so far almost unnoticed in botany (Cody \& Mooney, 1978).

(3) Oases. The largest concentration of Sudanian species is found in the moist habitats of oases. Species existing in these conditions enjoy both high temperatures and a relative abundance of water. Here can be found arboreal Sudanian species generally uncommon in the Dead Sea Rift due to the rarity of oases. Around the Dead Sea, the major large oases are Ein Gedi, Safi, and Kallirhoi. Sudanian species non-existent in other parts of the Levant (Israel, Lebanon, Syria, and Jordan) grow in these oases. Worthy of mention are Maerua crassifolia, Capparis decidua, Acacia laeta, and Cordia sinensis.

(4) Warm salines. The geomorphological structure of the Dead Sea Rift gives rise to undrained depressions ("Ka"-Evenari et al., 1982) with permanently high ground water where saline conditions occur. In addition, saline habitats occur around the Dead Sea near springs and alluvial fans of large wadis (Zohary, 1945; Zohary \& Orshan, 1956).

The majority of the species occurring in these saline depressions are Saharo-Arabian elements; only a few Sudanian taxa are present, yet they are prominent. The species worth noting are Suaeda monoica, S. fruticosa, and Tamarix spp. These species belong to a peculiar phyto-geographical group (Zohary, pers. comm.) distributed from central Asia all the way to South Africa. They occur throughout the Sudanian (or Sudano-Zambesian) region but are not restricted to it. It is unclear whether their center of origin is Irano-Turanian, Sudanian, or South African. They might even represent part of the "paleoWelwitchia flora" that connected the ancient deserts of Asia and Africa (Zohary, 1973).

Two additional ancient elements of tropical origin that are concentrated primarily in these saline habitats are the sole two palm species that occur in Israel. The first is the doum palm $\mathrm{Hy}$ phaene thebaica that, in Israel, grows exclusively in the high-groundwater salt marshes of the southern Arava and along the Gulf of Eilat. The second palm species of Sudanian origin is the date palm Phoenix dactylifera, whose center of origin has been a subject of controversy for cen- 


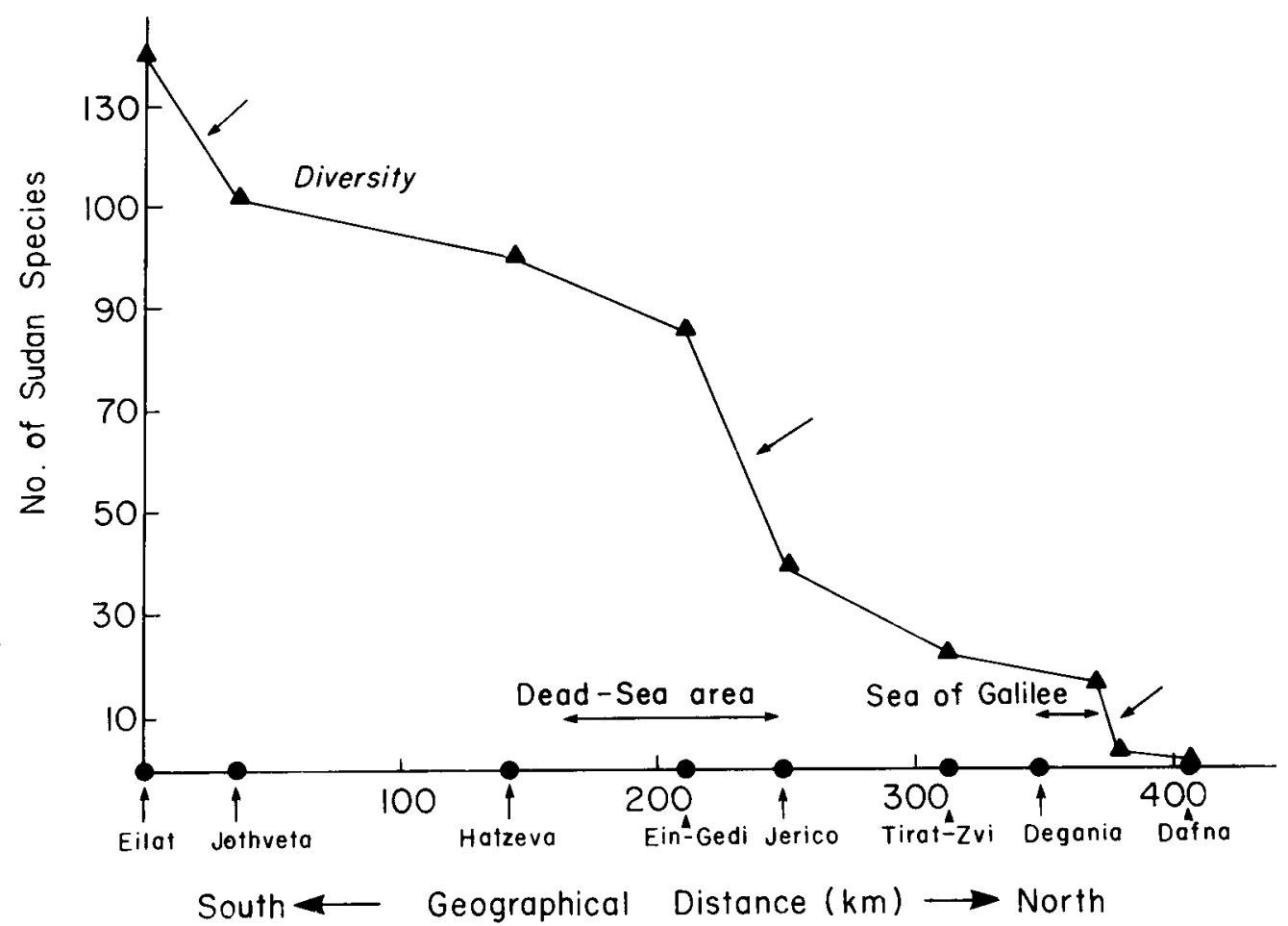

FIgURE 7. Sudanian species diversity along the Dead Sea Rift axis.

turies. As a result of human introduction, cultivated or feral $P$. dactylifera is now found in virtually every desert oasis in Africa, the Middle East, and adjacent regions (Chevalier, 1938; Zohary \& Spiegel-Roy, 1975). However, throughout the Saharo-Arabian and Sudanian regions of its present range, it is almost impossible to differentiate between natural and introduced populations. In some of the salines where the species occurs in the Dead Sea Rift Valley, the populations may well be subspontaneous, i.e., escapes from cultivation, but we assume it is indigenous to the area and not an introduction from far away (Zohary, 1982). The salt marshes at Neot HaKikkar and in the Beit Shean Valley might be typical of the kind of natural habitat from which the date palm was originally dispersed to other saline and freshwater springs in nearby desert areas.

\section{DISTRIBUTION PATTERNS AS FUNCTIONS OF ENVIRONMENTAL CONDITIONS ALONG THE DEAD SEA RIFT}

Figure 6 illustrates the opposing gradients of mean annual temperatures and precipitation along the length of the Dead Sea Rift. Progressing south from the Dan Valley, the mean annual precipitation decreases from 600 to $27 \mathrm{~mm}$ at Eilat (Anonymous, 1970). In contrast, the mean temperatures of the warmest and coldest months increase from 36.4 to $40.2^{\circ} \mathrm{C}$ in the north and from 7.8 to $10.1^{\circ} \mathrm{C}$ in the south (Anonymous, 1970).

As described in the preceding section, in areas with insufficient rainfall, the existence of specialized micro-habitats with improved water regimes, combined with the ability of the Sudanian elements to undergo habitat shifts can in part compensate for the overall paucity of precipitation (Boyko, 1947). However, the thermophilic Sudanian elements can only partially contend with low temperatures such as are found north of the Jerusalem-Jericho line, by contracting to southern exposures with increased insolation. Thus, from the standpoint of temperature adaptation, the number of Sudanian species should increase to the south; however, the opposite is true in terms of rainfall requirements. The finding that the overall number of Sudanian species along the Dead Sea Rift decreases from south to north, both absolutely and in relation to the total 


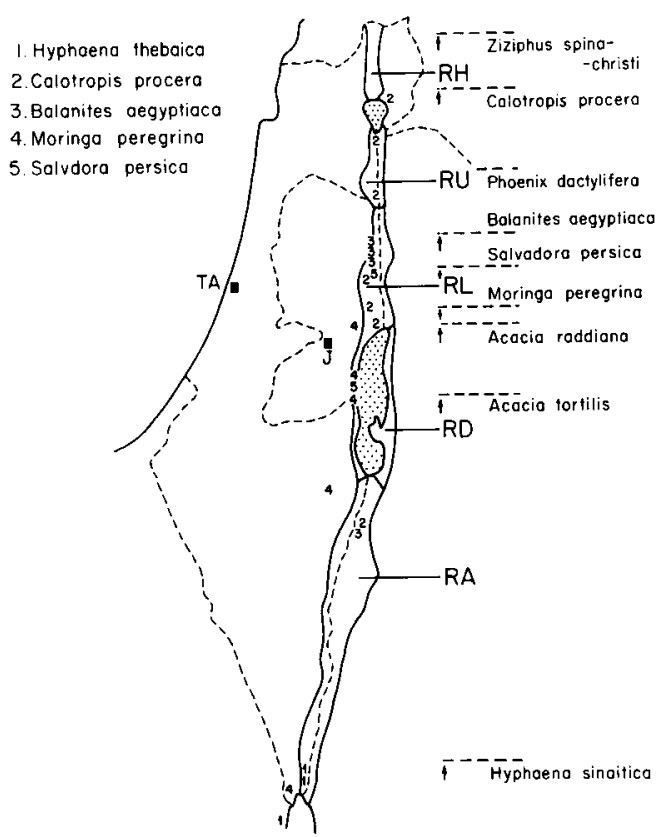

FIGURE 8. Northern distribution borders of typical arboreal Sudanian elements in the Dead Sea Rift. RAArava region, RD-Dead Sea region, RL-Lower Jordan Valley, RU-Upper Jordan Valley, RH-Huleh Valley. Numbers indicate solitary distribution points of rare Sudanian trees.

vegetation cover of the area (Fig. 7), is parallel to the decreasing temperature gradient from south to north.

Figures 8 and 9 show several typical Sudanian species according to their northernmost distribution limit in the Dead Sea Rift. For the purpose of presentation and due to the existence of relatively sharp geomorphological climatic borders along the Rift, we have grouped the plants according to distribution (Table 3). Most of the "Eilat group" are associated with the igneousmetamorphic rock matrix as well as with high temperatures. The distribution of the largest group of Sudanian species ends in the Ein GediWadi Kelt area (about $20 \%$ of the Sudanian species). This may be related to the especially high temperature in this area due to the deep topographical "hole" of the Dead Sea (399 m below sea level) and also to the existence of appropriate habitats such as rocky cliffs and oases. Additional Sudanian species end gradually between the Dead Sea and the Sea of Galilee. The last topographical barrier, the Corrasim Saddle, which rises from the Sea of Galilee $(-212 \mathrm{~m})$ to the Hula Valley (30-180 $\mathrm{m}$ above sea level),

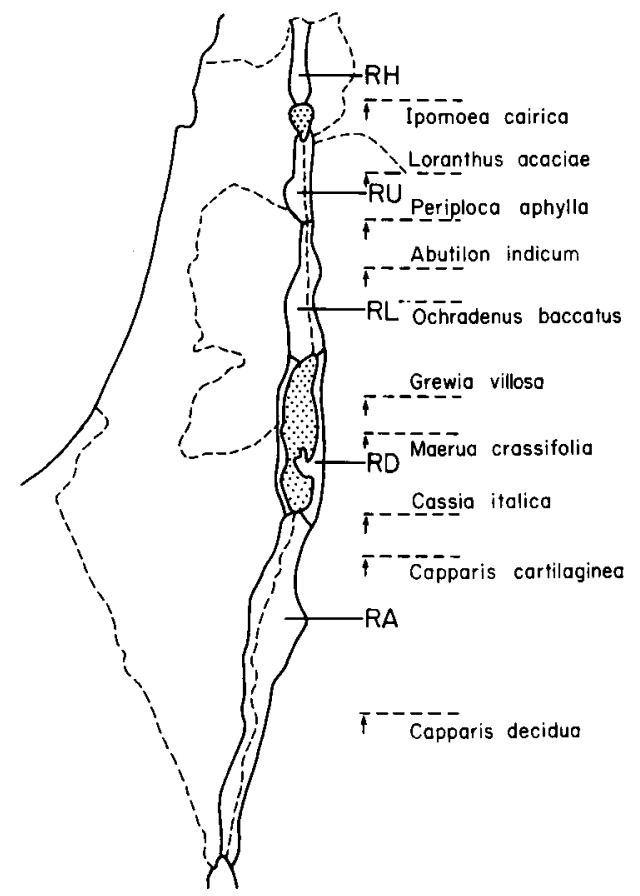

FiguRE 9. Northern distribution borders of small shrubs and woody vines in the Dead Sea Rift Valley.

probably presents a drastic climatic change through which none of the Sudanian species have yet broken. North of the Sea of Galilee there are almost no true Sudanian elements. Accordingly, the Rift is the world's northern limit (locus terminus) for most Sudanian species.

There is, however, one phenomenon that seems to contradict the decreasing gradient of Sudanian species from south to north: the population densities of certain Sudanian species increase to the north from the Dead Sea to Mt. Gilboa, where the annual precipitation reached $150-300 \mathrm{~mm}$ (Fig. 2). These species, while rare or completely absent from the extremely dry Arava Valley south of the Dead Sea, are common north of it and even form their own communities and dominate the landscape. Three distribution groups are found among these species: (1) plants growing near springs, mainly around the Dead Sea, e.g., Salvadora persica, Balanites aegyptiaca, (2) cliff vegetation such as Periploca aphylla, Sonchus tuberosus, and Iphiona maris-mortui, and (3) plants growing in rock crevices that absorb large amounts of runoff water, such as Moringa peregrina, Grewia villosa, and Abutilon indicum.

These three habitats are more common around the northern end of the Dead Sea (due to its 
special geomorphology) than in other regions of the Rift. Thus, the frequency of the habitats here can explain the "abnormal" abundance of the Sudanian species around the Dead Sea itself.

\section{TAXA ENDEMIC TO THE DEAD SEA RIFT VALLEY}

Species in small enclaves outside their main area of distribution have a higher probability of speciation (Stebbins, 1952, 1971) so that an ancient population cut off from its principal area of distribution for thousands or even millions of years may differentiate to the species or even genus level. By contrast, a population isolated for only some hundreds or thousands of years can be expected to differentiate only to the level of forms or varieties, if at all.

Thus one method for determining whether the Sudanian vegetation in the Dead Sea Rift is a Miocene relict or the result of recent invasion is to compare the degree of speciation of Sudanian species in the Dead Sea Rift Valley with that of (1) related taxa in the Sudanian region of east Africa and (2) species from other phytogeographical regions growing in the Dead Sea Rift Valley, such as true desert elements.

Another rule of thumb used by many biogeographers is that the more ancient and isolated the vegetation in an enclave, the greater the chances of finding systematic relicts in it (Shmi$\mathrm{da}, 1985)$. Thus, if Sudanian vegetation has been present in the Dead Sea Rift since the Miocene, at least some relict taxa with no close systematic relatives and whose distribution areas do not extend outside the Dead Sea Rift, should be found. This is a phenomenon known from other similarly isolated regions, such as the Inyo region in southern California, where many relicts have been recorded (Reveal, 1976; Raven, 1977). For a detailed probability analysis of these two biogeographic rules see Shmida (1985).

We find systematic relicts almost totally absent from the area. This fact is striking in view of the seemingly ideal conditions for speciation in which the various Sudanian species occur in the Rift Valley (small, remote, and disjunct populations subject to extreme desert stress, see Stebbins, 1952). A possible exception is Trichodesma boissieri, a chasmophyte endemic to the region between Ein Gedi and Mt. Gilboa. This species is unrelated to others in the genus found in the Dead Sea Rift and Sinai ( $T$. africana and $T$. ehrenbergii) and is probably both a systematic and geographic relict. Trichodesma boissieri may continue southwards to Yemen through the Arabian Peninsula, but this area is one of the least investigated in the Old World, and no data are available.

Table 4 presents the list of species endemic to the Dead Sea Rift. Only four of them are of certain Sudanian origin and they are limited to the Sdom-Wadi Kelt area. Thirteen species are endemic to the Dead Sea Rift and the Judean Desert and are not of Sudanian origin but derived from other, nearby phytogeographic regions. Most of the endemic species (except for Trichodesma boissieri) have allopatric sibling relatives with continuous morphological changes in intermediate populations nearby. Sonchus suberosus (Feinbrun-Dothan, 1978) may be another paleoendemic but, owing to its uncertain pre-taxonomic position (compare Boulos, 1962), its taxonomic-evolutionary position is unclear. This pattern hints at the relative youth of the speciation process in the Dead Sea Rift area. If the populations in this area had been isolated from each other for many thousands of years, clear morphological disjunctions would be expected within pairs of main species. If that were the case, the gradual geographical-morphological transition between them would not be discernible at present. We might also expect to see, in at least some of the species, the additional evolutionary step of sympatric expansion and differentiation to different niches. (There are many such examples recorded for other regions, see Mayr, 1970; MacArthur, 1972). Yet none of the species endemic to the Dead Sea Rift or Sudanian species in Israel follows this pattern.

Among Sudanian trees and shrubs, no varieties and certainly no species endemic to the Dead Sea Rift have been found, with the sole exception of Maerua crassifolia var. maris-mortui (Zohary, 1955). However, it is worth remembering that the speciation process of arboreal species is slower than that of herbaceous and annual ones (Stebbins, 1971; Davis \& Heywood, 1963). Most of the arboreal Sudanian species in Israel have very large geographic ranges, from the southern Sahara through southern Arabia to southern Iran and India (Fig. 2). Examples are Calotropis procera, Capparis decidua, Cassia italica, Grewia villosa, Maerua crassifolia, and Ochradenus baccatus. Some of these taxa spread even further south along the east African savannas to South Africa (Werger, 1978). The distribution of the genus Moringa (Fig. 10) exemplifies this distribution pattern. The distribution maps of the ge- 
TABLE 3. Geographical distribution of some Sudanian elements in Israel.a

\begin{tabular}{|c|c|c|c|}
\hline \multicolumn{4}{|c|}{ Northern Limit of Distribution in the Dead Sea Rift } \\
\hline Eilat District & Hatzeva District & $\begin{array}{c}\text { Dead Sea (Ein Gedi) } \\
\text { District }\end{array}$ & $\begin{array}{c}\text { Jericho-Wadi Kelt } \\
\text { District }\end{array}$ \\
\hline $\begin{array}{l}\text { Anticharis glandulosa } \\
\text { Astragalus sparsus } \\
\text { Cassia senna } \\
\text { Cleome chrysantha } \\
\text { Cometes abyssinica } \\
\text { Eremopogon foveolatus } \\
\text { Glossonema boveana } \\
\text { Hyphaena thebaica } \\
\text { Lindenbergia sinaica } \\
\text { Monsonia heliotropioides } \\
\text { Moretia canescens } \\
\text { Otostegia schimperi } \\
\text { Pterogaillonia calycoptera } \\
\text { Pycnocycia tomentosa } \\
\text { Seetzenia orientalis } \\
\text { Tephrosia nubica }\end{array}$ & $\begin{array}{l}\text { Bothriochloa ischae- } \\
\quad \text { mum } \\
\text { Crotalaria aegyptiaca } \\
\text { Laisiurus scindicus } \\
\text { Leptadenia pyrotechni- } \\
\quad \text { ca } \\
\text { Leysera leyseroides } \\
\text { Pentatropis spiralis } \\
\text { Oxystelma alpini } \\
\text { Tephrosia apollina }\end{array}$ & $\begin{array}{l}\text { Abutilon hirtum } \\
\text { Acacia tortilis } \\
\text { Capparis decidua } \\
\text { Cleome droserifolia } \\
\text { Convolvulus glom- } \\
\quad \text { eratus } \\
\text { Cordia sinensis } \\
\text { Grewia villosa } \\
\text { Hibiscus micran- } \\
\text { thus } \\
\text { Maerua crassifolia } \\
\text { Pergularia tomento- } \\
\quad \text { sa } \\
\text { Pulicaria inuloides } \\
\text { Stipagrostis hirti- } \\
\text { gluma } \\
\text { Zygophyllum sim- } \\
\text { plex }\end{array}$ & $\begin{array}{l}\text { Abutilon fruticosum } \\
\text { A. hirtum } \\
\text { Acacia raddiana } \\
\text { Aerva persica } \\
\text { Aizoon canariense } \\
\text { Chrozophora oblongifolia } \\
\text { Cleome amblyocarpa } \\
\text { Forsskaolea tenacissima } \\
\text { Iphonia mucronata subsp. } \\
\quad \text { maris-mortui } \\
\text { Lavendula pubescens } \\
\text { Moringa peregrina } \\
\text { Ochradenus baccatus }\end{array}$ \\
\hline
\end{tabular}

nus Balanites (Fig. 11) and Salvadora (Fig. 12) illustrate different kinds of distribution patterns within the Sudanian group.

In conclusion, the extant environmental and genecological conditions in the Dead Sea Rift Valley are potentially ideal for speciation (Stebbins, 1952; 1972). The Sudanian species there are represented by small isolated populations, separated by thousands of kilometers from their center of distribution in east Africa. In comparison to prevailing conditions in the east African savannas, many of the habitats of these species have changed drastically, and the species survive under extremely arid climatic conditions. All these factors are indicative of exceptionally strong selective pressures that should have led to rapid speciation within the isolated populations (Stebbins, 1972). However, just the opposite has occurred in the Dead Sea Rift Valley. Very few species have undergone speciation, and when they have, it is only to the variety or subspecies level. In contrast, a relatively high rate of endemism occurs in the Judean Desert, which borders the Dead Sea Rift Valley, consisting mainly of Saharo-Arabian and Irano-Turanian species. These distribution and speciation patterns seem to support the argument that the Sudanian elements in Dead Sea Rift Valley are of recent origin.

\section{Distribution AND ECOLOGY OF THE SUDANIAN ELEMENTS IN ISRAEl OUTSIDE THE DEAD SEA RIFT}

The distribution of a few Sudanian species in Israel is not limited to the Dead Sea Rift and the thermic wadis of the Negev but also extends into the Mediterranean region (see Fig. 2). These more widespread species represent only about $10 \%$ of the Sudanian elements in Israel, but their ecological "behavior" and distribution patterns shed additional light on the question of the relative antiquity of all the Sudanian elements in Israel.

The majority of the Sudanian elements occurring outside the Dead Sea Rift are found primarily in disturbed secondary habitats created, or at least heavily influenced, by human activity. This fact has led to the formulation of the widely accepted theory, expressed by Zohary (1973), that these species, once limited to the Arava Valley in the southern portion of the Dead Sea Rift and to the few scattered oases and saline marshes in the Rift, gradually spread north and west over large areas of the country; this expansion was made possible by the greatly intensified agricultural and settlement activities of the last century. However, some clear and some apparent exceptions to this rule are recognizable, namely in the group of Sudanian aquatic elements and the few 
TABle 3. Continued.

\begin{tabular}{|c|c|c|c|c|}
\hline \multicolumn{2}{|c|}{$\begin{array}{c}\text { Northern Limit of Distribution in the } \\
\text { Dead Sea Rift }\end{array}$} & \multicolumn{3}{|c|}{ Species Penetrating into the Mediterranean Region } \\
\hline $\begin{array}{c}\text { Beit Shean } \\
\text { District }\end{array}$ & $\begin{array}{c}\text { Sea of Galilee } \\
\text { District }\end{array}$ & $\begin{array}{l}\text { Fully Integrated } \\
\text { Elements }\end{array}$ & Ruderals & $\begin{array}{l}\text { Aquatics and } \\
\text { Hygrophiles }\end{array}$ \\
\hline $\begin{array}{l}\text { Balanites aegyptia- } \\
\text { ca } \\
\text { Cucumis prophetar- } \\
\quad \text { um } \\
\text { Loranthus acaciae } \\
\text { Periploca aphylla } \\
\text { Salvadora persica } \\
\text { Trichodesma boissi- } \\
\text { eri }\end{array}$ & $\begin{array}{l}\text { Bocopa monnieri } \\
\text { Calotropis procera } \\
\text { Commicarpus verti- } \\
\quad \text { cillatus } \\
\text { Ipomoea cairica } \\
\text { Tricholaena teneriffae }\end{array}$ & $\begin{array}{l}\text { Aristida sieberiana } \\
\text { Commicarpus afri- } \\
\quad \text { canus } \\
\text { Desmostachya bipin- } \\
\quad \text { nata } \\
\text { Epipactis consimilis } \\
\text { Hyparrhenia hirta } \\
\text { Ipomoea cairica } \\
\text { Pennisetum setaceum } \\
\text { Ziziphus spina-christi }\end{array}$ & $\begin{array}{l}\text { Chrozophora } \\
\text { tinctoria } \\
\text { Withania somnif- } \\
\text { era }^{\mathrm{b}}\end{array}$ & $\begin{array}{l}\text { Bacopa monni- } \\
\text { eri } \\
\text { Cyperus jemini- } \\
\text { cus } \\
\text { Nymphaea ceru- } \\
\quad \text { la } \\
\text { Vigna lutea }\end{array}$ \\
\hline
\end{tabular}

Only well-documented unambiguous cases are included.

b These species are included here despite the fact that Zohary (1973) did not record its chorotype as Sudanian, since its Sudanian vicariads are very close - both geographically and systematically. Therefore we assume that it is an instance of a recently derived species of Sudanian origin.

species that appear to be fully integrated today with the predominant Mediterranean vegetation in the coastal plain. The three groups of the Sudanian elements-Ruderals, Aquatics and $\mathrm{Hy}$ drophiles, and Fully Integrated-will be discussed in turn, along with an Anomalous group.

\section{RUDERALS}

The most prominent of the Sudanian elements that has rapidly expanded and continues to expand into disturbed sites outside the Dead Sea Rift is the so-called Syrian Christ-Thorn, Ziziphus spina-christi. The present distribution of this tree, whose edible fruits are dispersed by birds and mammals, includes the valleys of the central plain and Galilee and even some lowlying regions of the central Negev. Within the Rift, it extends all the way to the Dan Valley, i.e., farther north than any other Sudanian arboreal element in Israel. However, a striking dichotomy occurs within the different portions of this extended distribution area. In the Rift Valley up to the Sea of Galilee and in the southern part of the coastal plain, $Z$. spina-christi is evergreen. By contrast, in areas north of the Sea of Galilee and in the northern portion of the coastal plain, it is winter deciduous (Danin, pers. comm.). We hesitate to call the corresponding areas primary and secondary habitats for $Z$. spina-christi, but there can be little doubt that the colder areas to the north represent areas into which Ziziphus has recently spread, and is continuing to spread, particularly along roadsides and in abandoned fields. By contrast, the part of the coastal plain where the tree is evergreen may be-together with the southern part of the Rift Valley-part of the species "primary" or natural distribution area in Israel. (For this reason, Ziziphus is discussed again below in the section on fully integrated elements.)

Several additional ruderal species among the Sudanian elements are found in the Gramineae. The Sudanian grasses Hyperrhenia hirta and Pennisetum setaceum, to take two major examples, were formerly limited to southern exposures in the Rift Valley. As a result of intensified human activity, they have recently spread over large areas of the Mediterranean region (Litav, 1967). They are especially dominant along roadsides in low-lying areas along the coastal plain. The northerly penetrations of these grasses 
TABLE 4. List of the endemic plant species restricted to the Dead Sea Rift Valley.

\begin{tabular}{|c|c|c|c|c|}
\hline Endemic Species & $\begin{array}{l}\text { Vicarious } \\
\text { Species from } \\
\text { Which it } \\
\text { Probably } \\
\text { Originated }\end{array}$ & $\begin{array}{l}\text { Chorotype } \\
\text { of the } \\
\text { Parent } \\
\text { Taxa }\end{array}$ & Habitat & $\begin{array}{l}\text { Type of Distribu- } \\
\text { tion and Speciation }\end{array}$ \\
\hline 1. Anthemis maris-mortui & A. hebronica & $\begin{array}{l}\text { Irano-Turani- } \\
\text { an }\end{array}$ & Thermic slopes & $\begin{array}{l}\text { Allopatric distribu- } \\
\text { tion with gradual } \\
\text { transition }\end{array}$ \\
\hline 2. Blepharis attenuata & B. ciliaris & Sudanian & Thermic slopes & $\begin{array}{l}\text { Parapatetic distribu- } \\
\text { tion with transi- } \\
\text { tions }\end{array}$ \\
\hline 3. Centaurea lanata & C. aegyptiaca & $\begin{array}{l}\text { Saharo-Ara- } \\
\text { bian }\end{array}$ & $\begin{array}{l}\text { Rocks \& wadis } \\
\text { of Judean } \\
\text { Desert }\end{array}$ & $\begin{array}{l}\text { Allopatric distribu- } \\
\text { tion, no transition } \\
\text { observed }\end{array}$ \\
\hline 4. Fagonia grandifolia & F. mollis & $\begin{array}{l}\text { Saharo-Ara- } \\
\text { bian }\end{array}$ & $\begin{array}{l}\text { Slopes of Ju- } \\
\text { dean Desert }\end{array}$ & $\begin{array}{l}\text { Allopatric distribu- } \\
\text { tion with gradual } \\
\text { transition }\end{array}$ \\
\hline 5. Galium hierochuntinum & G. judaicum & Mediterranean & $\begin{array}{l}\text { Rocks \& wadi } \\
\text { beds in can- } \\
\text { yons }\end{array}$ & $\begin{array}{l}\text { Allopatric distribu- } \\
\text { tion with gradual } \\
\text { transition }\end{array}$ \\
\hline 6. Hammada eigii & H. scoparia & $\begin{array}{l}\text { Irano-Turani- } \\
\text { an }\end{array}$ & $\begin{array}{l}\text { Slopes \& collu- } \\
\text { vium }\end{array}$ & $\begin{array}{l}\text { Allopatric distribu- } \\
\text { tion with disjunc- } \\
\text { tion }\end{array}$ \\
\hline 7. Heliotropium maris-mortui & H. rotundifolium & $\begin{array}{l}\text { Irano-Turani- } \\
\text { an }\end{array}$ & $\begin{array}{l}\text { Slope of Judean } \\
\text { Desert }\end{array}$ & $\begin{array}{l}\text { Allopatric distribu- } \\
\text { tion with gradual } \\
\text { transition }\end{array}$ \\
\hline 8. Iphiona maris-mortu ${ }^{\mathrm{b}}$ & 1. mucronata & Sudanian & Cliffs \& rocks & $\begin{array}{l}\text { Allopatric distribu- } \\
\text { tion with disjunc- } \\
\text { tion of tens of km }\end{array}$ \\
\hline 9. Kickxia judaica & K. acerbiana & $\begin{array}{l}\text { E. Saharo-Ara- } \\
\text { bian }\end{array}$ & Cliffs \& rocks & $\begin{array}{l}\text { Allopatric distribu- } \\
\text { tion with gradual } \\
\text { transition }\end{array}$ \\
\hline 10. Matthiola aspera & M. livida & $\begin{array}{l}\text { Saharo-Ara- } \\
\text { bian }\end{array}$ & $\begin{array}{l}\text { Slopes of Ju- } \\
\text { dean \& Jer- } \\
\text { icho Desert } \\
\text { valley }\end{array}$ & $\begin{array}{l}\text { Allopatric distribu- } \\
\text { tion with gradual } \\
\text { transition }\end{array}$ \\
\hline 11. Podonosma syriaca & $\begin{array}{l}\text { P. syriaca var. } \\
\text { typica }\end{array}$ & Mediterranean & Rocks & $\begin{array}{l}\text { Allopatric distribu- } \\
\text { tion with gradual } \\
\text { transition }\end{array}$ \\
\hline 12. Sonchus suberosus & $\begin{array}{l}\text { S. suberosus ssp. } \\
\text { suberosus }\end{array}$ & Sudanian & Cliffs \& canyons & $\begin{array}{l}\text { Allopatric distribu- } \\
\text { tion with disjunc- } \\
\text { tion of hundreds } \\
\text { of } \mathrm{km}\end{array}$ \\
\hline 13. Reseda maris-mortui & $R$. boissieri & $\begin{array}{l}\text { Saharo-Ara- } \\
\text { bian }\end{array}$ & Thermic slopes & $\begin{array}{l}\text { Allopatric distribu- } \\
\text { tion with gradual } \\
\text { transition }\end{array}$ \\
\hline 14. Silene oxydonta ${ }^{\mathrm{b}}$ & $?$ & $\begin{array}{l}\text { Irano-Turani- } \\
\text { an }\end{array}$ & In wadi beds & $?$ \\
\hline 15. Suaeda asphaltica & $?$ & $\begin{array}{l}\text { Saharo-Ara- } \\
\text { bian-Irano- } \\
\text { Turanian }\end{array}$ & Chalky slopes & No transition \\
\hline 16. Tamarix palaestina & $T$. jordanis & $\begin{array}{l}\text { Irano-Turani- } \\
\text { an }\end{array}$ & Wet habitat & $\begin{array}{l}\text { Allopatric distribu- } \\
\text { tion }\end{array}$ \\
\hline 17. Trichodesma boissieri & $?$ & Sudanian & $\begin{array}{l}\text { Rock outcrop- } \\
\text { ping }\end{array}$ & $\begin{array}{l}\text { No transition or al- } \\
\text { lied }\end{array}$ \\
\hline
\end{tabular}

The taxonomical rank of these taxa has recently been lowered to varieties.

b Very rare. 


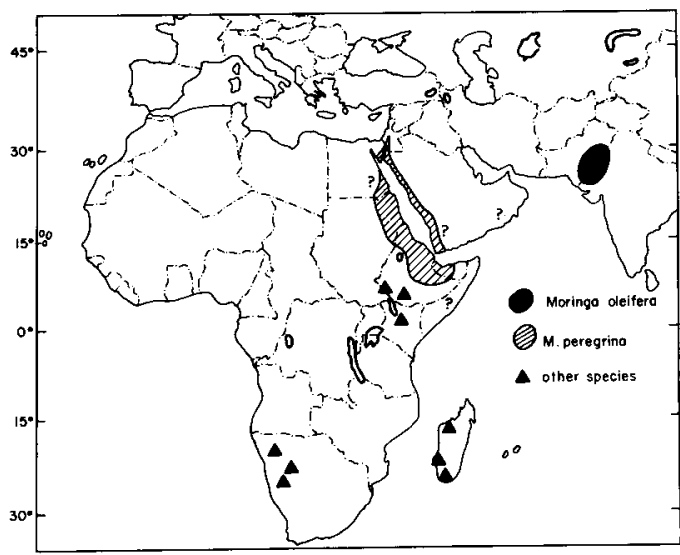

Figure 10. Distribution map of some Moringa spp. (after Kerauden, 1965).

are probably accomplished with the aid of physiological-biochemical adaptations of new populations to lower and lower temperatures.

Other examples of savanna grasses turned ruderal include Desmostachya bipinnata and $\mathrm{Ar}$ istida sieberiana. As was mentioned with respect to Ziziphus spina-christi, so again in the grasses, a certain transitional character must be examined. Within the Rift Valley most of these grasses occur strictly in moist habitats, salt marshes, or rocky outcrops-or more recently, as weeds in plowed fields and along roadsides. In the warm, moist parts of the coastal plain, where they occur in far fewer numbers, they are found in disturbed

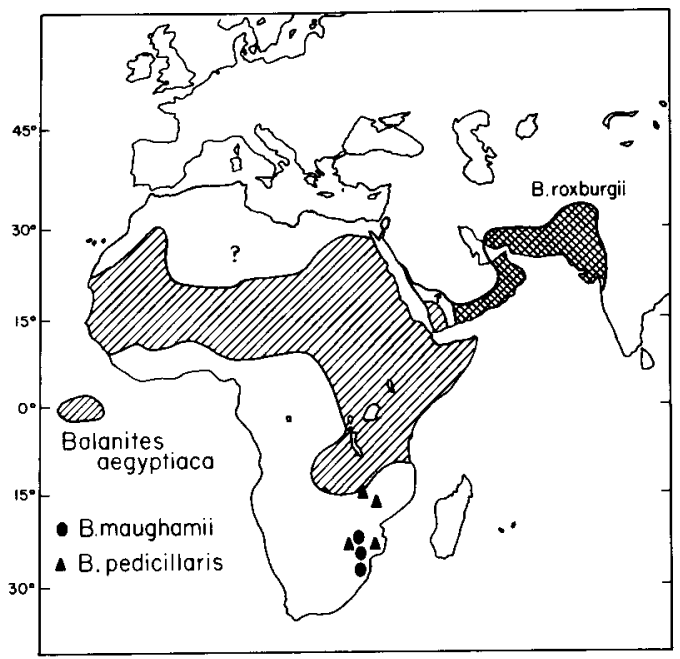

FIGURE 11. Distribution map of some Balanites spp. (with the assistance of M. J. S. Sands).

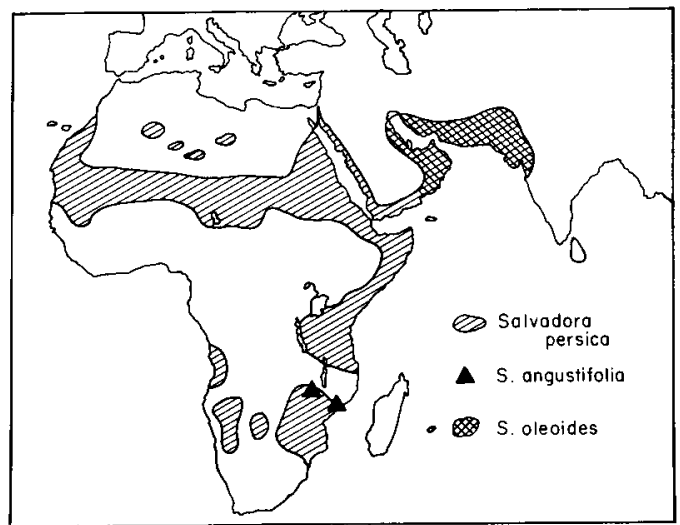

FIGURE 12. Distribution map of some Salvadora spp.

sites. However, in some cases they also appear to be well integrated in the oak woodland association, as will be discussed below.

\section{AQUATICS AND HYDROPHILES}

A second group of Sudanian elements found mainly outside the Sudanian enclave of the Rift are hydrophilic species. Some of these grow in swamps or other perennially aquatic habitats (e.g., Cyperus jeminicus, Nymphaea alba, and Vigna luteola). Others grow in moist recesses from which they have migrated to cultivated fields (e.g., Chrozophora tinctoria, C. plicata, and Commicarpus africanus). Those areas of primary wet habitats in which the water level and channels can change rapidly and unpredictably are populated in part by species pre-adapted to secondary habitats such as roadsides and cultivated fields.

\section{FULLY INTEGRATED SUDANIAN ELEMENTS}

Desmostachya bipinnata is an important Sudanian grass that grows in a variety of soils in the east African savannas (Wickens, pers. comm.) and in the Thar Desert (Bhandari, 1978). In the Arava it is dominant in salt marsh and saline sand communities. Along the coastal plain it occurs in the natural oak woodland community of Quercus ithaburensis on red sandy loam (Eig, 1946; Zohary, 1955). This thermophilic plant community also includes additional Sudanian components such as Aristida sieberiana, Stipagrostis obtusifolia, and Ziziphus spina-christi. The Quercus ithaburensis-Desmostachya bipinnata association is part of a broad transitional trend 


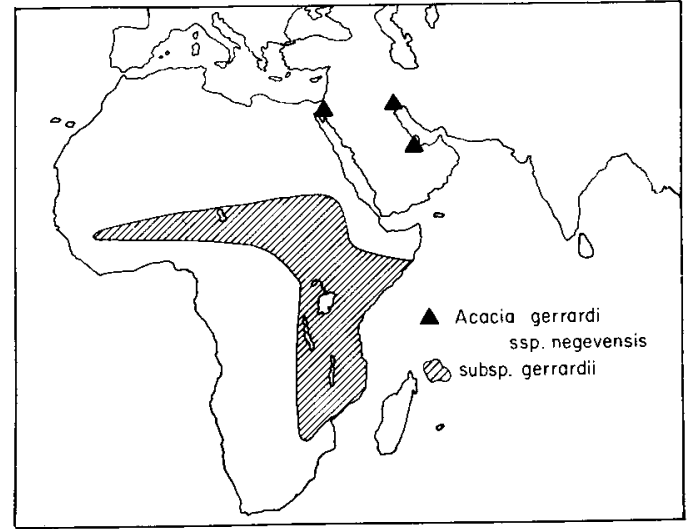

Figure 13. Distribution of Acacia gerrardii subsp. negevensis and subsp. gerrardii (after Halevy, 1971; Ross, 1966; Wickens, pers. comm.).

from the holarctic to the tropical regions. A similar transition gradient occurs in North America, where northern oaks, along with tropical Prosopis and Poaceae constitute the "savanna" vegetation in parts of southern Texas and southern Arizona (Whittaker et al., 1979). In this oak woodland community of the coastal plain is found the only recorded endemic Sudanian species in Israel occurring entirely outside the Dead Sea Rift-Aristida sieberiana. The geneticsystematic relatives of this grass species are not clear, and considerable controversy exists on the endemic status of this taxon (Feinbrun, pers. comm.). Further studies may alter its current status.

As mentioned above, both Ziziphus spinachristi and some of the grasses belong both to the ruderal group and to the group of fully-integrated species. In fact a Ziziphus spina-christiHyparrhenia hirta community is recognized along the coastal plain. Zohary (pers. comm.) assumed that the climax area of this community occurred in the southern portion of the coastal plain. Due to intensive cultivation and woodcutting, however, not many locations remain that can still testify to this presumed climax vegetation. In the northern portion of the coastal plain, it is replaced by the Ceratonia siliqua-Pistacia lentiscus community that dominates the coastal foothills. Even in this community where most of the components are typical Mediterranean, the dominant species show a strong Sudanian affinity. For example, Ceratonia siliqua grows wild in the mountains of Yemen and clearly belongs to a tropical section within its family. Only recently, a new species of Ceratonia-C. oreothauma was discovered in isolated, disjunct regions of Arabia and Somalia providing further indication of a tropical origin for this genus (Hillcoat et al., 1980). Pistacia lentiscus is also reported from the colline regions of east Africa (Lind \& Morrison, 1974; Zohary, pers. comm.). At present, the principal distribution of both these species is in the colline belt around the Mediterranean Sea. Yet they exhibit both systematic and ecological (they are both evergreen sclerophyllous and thermophilic) links to the Sudanian tropical vegetation. Because the links are usually evident only at the generic level, Zohary $(1955,1973)$ assumed that they were very ancient links going back as far as the Miocene, when tropical vegetation dominated the entire Mediterranean region and central Europe.

\section{ANOMALOUS GROUP}

In addition to the three groups described above, two additional species should be mentioned that conform to none of the above patterns and theories. The first of these is Acacia gerrardii subsp. negevensis. The map in Figure 13 shows the distribution of Acacia gerrardii with geographical delineation of the two recognized subspecies. The generic distribution pattern reveals a remarkable degree of disjunction between subspecies negevensis in southern Israel and a few sites in southwestern Arabia and the more widespread subspecies gerrardii in eastern and southern Africa. Moreover, $A$. gerrardii subsp. negevensis does not occur, in Israel at least, in typical Sudanian conditions (Halevy, 1970). Instead of occupying wadi beds in the Arava Valley, such as are preferred by Acacia tortilis and $A$. raddiana, this subspecies grows in only a few adjacent watersheds in the highlands of the southern Negev and one or two sites in eastern Sinai. It appears to be adapted to cool habitats, which represents an ecological shift from its primary warm habitats, as seen in Africa. Its restricted geographical area and lack of penetration to adjacent cool, open areas (e.g., the Mt. Ramon Range and the Sante Katerina Highlands in Sinai) are indicative of an extreme relict position in the area. Further evidence for this view is provided by the anomalously disjunct pattern (southern Negev, eastern Sinai, Kuwait), which is unlike that of any other Sudanian species. Significantly, $A$. gerrardii subsp. gerrardii is also a watershed species throughout its range in Africa (see Fig. 13, Wick- 
ens, pers. comm.). Finally, it is worth noting that the Jordan Sparrow, Passer moabiticus, exhibits a similar disjunct pattern, occurring only in Israel, Jordan, and the Persian Gulf region (Boros \& Horvath, 1954; Kumerlove, 1971).

The second anomalous species is Acacia albida (= Faidherbia albida), which occurs in a few isolated sites of the Mediterranean coastal plain, a few sites in the Jordan Valley north of the Dead Sea, and one or two isolated spots elsewhere in the country (Halevy, 1971). It does not occur in the Negev or Arava Valley (Aaronsohn, 1913; Karschon, 1961; Aloni \& Orshan, 1972; see Fig. 14). Unlike its typical ecological patterns in Africa (Radwanski \& Wickens, 1967; Wickens, 1969; Ross, 1966, 1979, 1981), it is not restricted to riparian or high ground-water sites in Israel. It also differs in that flowering and fruiting are relatively rare in all the sites at which it occurs in Israel, while vegetative propagation by suckers is far more common (Halevy \& Orshan, 1972). Zohary (1962) has argued for the relict position of this species in Israel; indeed, the anomalous position of $A$. albida within the genus Acacia, and its occurrence with typical Mediterranean associations such as Artemisia monosperma and Cyperus mucronatus along the coastal plain, support that conclusion. However, the overall distribution pattern of the species in Israel (Fig. 14) and its atypical ecological characters here, could instead indicate a recent arrival and penetration to this area from the Nile River Basin rather than along the Syrio-Africa Rift.

Throughout Africa Acacia albida exhibits a phenological feature unusual to but not unique among savanna trees in that it sheds its leaves at the beginning of both rainy seasons (Wickens, 1969; Pelissier, 1977). In Israel, bi-annual shedding of the leaves occurs although there is only one rainy season per year. In the case of an ancient relict, we would expect this character to have been modified rather than preserved. Moreover, recent investigations on the northernmost branch of the Nile River indicate that as recently as the sixth century A.D. this so-called Pelusiac branch was active and extended a considerable distance into the northern Sinai Peninsula (Sneh \& Weissbrod, 1973). It does not seem impossible, therefore, that Acacia albida should have been gradually dispersed by one or more vectors along the Mediterranean coast and finally to the Jezreel Valley and Beit Shean on the one side and as far north as southern Lebanon on the other (Halevy, 1971).

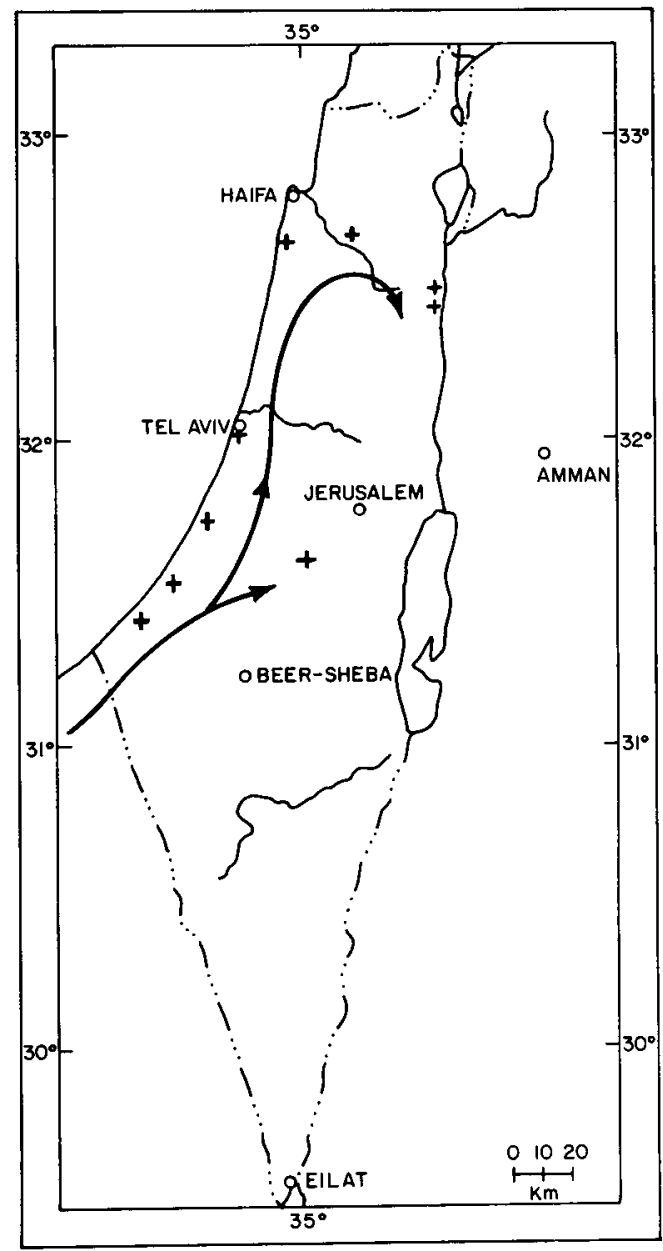

FIGURE 14. Distribution of Acacia albida in Israel. The arrows indicate the presumed penetration route (after Halevy, 1971).

\section{Adaptation of Sudanian SPecies to ARIDITY AND LONG-RANGE DISPERSAL}

Regardless of the age of the Sudanian elements found in Israel today the question naturally arises: how and why did some elements arrive (and remain) here and not others? Given that the Dead Sea Rift and the other regions in Israel in which Sudanian elements are found do not enjoy the same amounts of rain that fall in the Sudanian region proper, and that what rain does occur is concentrated in only one rainy season, it might be supposed that various adaptations or pre-adaptations to drought would be found in the Sudanian elements in Israel. Obviously, it is difficult or impossible to analyze such factors 
TABLE 5. Dispersal analysis of the Sudanian arboreal floras of Sudan, Egypt, and Israel (see text for details).

\begin{tabular}{|c|c|c|c|c|c|c|}
\hline \multirow{2}{*}{$\begin{array}{l}\text { Long-distance } \\
\text { Dispersal } \\
\text { Vector } \\
\end{array}$} & \multicolumn{2}{|c|}{ Sudana,d } & \multicolumn{2}{|c|}{ Egypt $^{\mathrm{b}, \mathrm{d}}$} & \multicolumn{2}{|c|}{ Israel $^{\mathbf{c}}$} \\
\hline & Number & Percent & Number & Percent & Number & Percent \\
\hline Wind & 56 & 14.0 & 11 & 8.5 & 9 & 18.4 \\
\hline Endozoochory & 189 & 47.25 & 73 & 56.1 & 22 & 44.9 \\
\hline Exozoochory & 2 & 0.5 & 8 & 6.2 & 4 & 8.1 \\
\hline None apparent & 153 & 38.25 & 38 & 29.2 & 14 & 28.6 \\
\hline Total & 400 & 100.0 & 130 & 100.0 & 49 & 100.0 \\
\hline
\end{tabular}

a Species list drawn from Andrews (1950-1956) and modified after Wickens (1968).

b Species list drawn from Täckholm (1974) with modifications.

c Species list drawn from Zohary and Feinbrun-Dothan (1966-1974), Feinbrun-Dothan (1978, 1985), and personal observations of the authors. Full species list with information on growth form, flowering period, chorotype, dispersal unit, and presumed dispersal vector is available from A. Shmida.

d Full species list with details of growth forms and presumed dispersal systems is available from the authors.

quantitatively, short of in situ field comparisons of the same species occurring in Sudan, for example, and in Israel.

On the other hand, a partial analysis of adaptations for long-distance dispersal of seeds is possible, on the basis of personal observations and study of the published floras of Israel, Egypt, and Sudan. Anemochory and zoochory would clearly facilitate more efficient dispersal of Sudanian elements to the Dead Sea Rift Valley and enable dispersal units or diaspores to reach the rare and disjunct habitats within the Rift that are suitable to their requirements. Members of the Asclepiadaceae (e.g., Calotropis, Periploca, Leptadenia, and Solenostemma) have a pseudopappus attached to each seed, which is clearly important in long-distance dispersal. Certain grasses (e.g., Pennisetum, Tetrapogon, and Tricholaena), Geraniaceae, Monsonia spp., and $\mathrm{Abu}$ tilon spp. have dispersal mechanisms very similar to those of the Asclepiadaceae.

Yet another ecological group with efficient longdistance dispersal mechanisms is the endozoochorous species, whose dispersal units are juicy berries eaten by birds (e.g., Maerua, Ephedra, Lycium, and Salvadora) or larger diaspores eaten by mammals and other large animals (e.g., Acacia, Balanites, Cordia, and Ziziphus). However, many Sudanian species in Israel lack any apparent long-distance dispersal mechanism.

Table 5 shows a comparison of the relative importance of the major long-distance dispersal vectors of seeds, anemochory and zoochory of trees, shrubs, and perennial vines in the Sudanian elements of Israel, Egypt, and Sudan excluding Equatoria Province. This analysis unavoidably relies to a certain extent on speculation; however, in all cases where no readily apparent morphological adaptation for long-distance dispersal was discernible, none was assumed. The flora of Sudan was chosen as the basis for comparison to Israel, since a fairly reliable flora was published rather recently (Andrews, 1950-1956) and considerable systematic work has been conducted in Sudan since then (cf. Wickens, 1968, 1977). All species occurring in the mountainous regions and Equatoria Province of Sudan, which are characterized by a moist tropical climate, were excluded from the analysis. The remaining portions of Sudan - the savannas, semidesert, and Red Sea Hills-were considered representative of the Sudanian phytogeographic region. Certainly, a west African region should have been compared as well, but we were unable to find a suitable flora.

In addition, the Sudanian elements of the arboreal flora of Egypt (Täckholm, 1974) were analyzed as a kind of mid-way station between Sudan and Israel. Finally, the Sudanian arboreal elements in Israel were analyzed in somewhat more detail; in almost all cases, the geographical ranges (chorotypes) were accepted as given by Zohary and Feinbrun-Dothan (1966-1974) and Feinbrun-Dothan $(1978,1985)$.

We concentrate only on the arboreal elements in each of the three countries for two main reasons: 1) the dispersal spectra and taxonomy of the non-arboreal floras of Egypt and Sudan are less well-known; and 2) the arboreal floras of Egypt and Israel are presumed to give the best picture of the "permanent" Sudanian elements to be found there. We have excluded arboreal elements characterized by Irano-Turanian or other non-Sudanian chorotypes e.g., Pistacia, 
TABLE 6. Habitat shifts of some Sudanian elements in different geographical areas.

\begin{tabular}{|c|c|c|c|}
\hline Name & Sudan & $\begin{array}{l}\text { Dead Sea } \\
\text { Rift Valley }\end{array}$ & $\begin{array}{l}\text { Outside Dead Sea Rift } \\
\text { Valley, esp. Coastal Plain }\end{array}$ \\
\hline \multicolumn{4}{|r|}{. } \\
\hline Acacia albida & $\begin{array}{l}\text { high ground water or } \\
\text { flood plains (habitat) }\end{array}$ & -5 & $\begin{array}{l}\text { a variety of diversified habi- } \\
\text { tats-sands, basaltic slopes, } \\
\text { and dry wadi beds }\end{array}$ \\
\hline $\begin{array}{l}\text { Acacia gerrardii ssp. } \\
\text { gerrardii }\end{array}$ & flood plains & $\begin{array}{l}\text { wadibeds in extreme } \\
\text { cold desert }\end{array}$ & - \\
\hline Balanites aegyptiaca & $\begin{array}{l}\text { scattered trees in sa- } \\
\text { vanna }\end{array}$ & oases and rocky cliffs & - \\
\hline $\begin{array}{l}\text { Moringa peregrina } \\
\text { Ziziphus spina-christi }\end{array}$ & $\begin{array}{l}\text { Red Sea Hills; savanna } \\
\text { scattered trees in sa- } \\
\text { vanna }\end{array}$ & $\begin{array}{l}\text { oases and rocky cliffs } \\
\text { oases and moist wadi } \\
\text { beds }\end{array}$ & ruderal, segetal \\
\hline \multicolumn{4}{|l|}{ Halophytes } \\
\hline $\begin{array}{l}\text { Desmostachya bipin- } \\
\text { nata }\end{array}$ & savanna grass & saline sinks & oak woodland \\
\hline Hyphaene thebaica & sparse in savanna & saline marshes & - \\
\hline Phoenix dactylifera & introduced; naturalized & $\begin{array}{l}\text { oases and saline marsh- } \\
\text { es }\end{array}$ & - \\
\hline \multicolumn{4}{|l|}{ Vines } \\
\hline $\begin{array}{l}\text { Cocculus pendulus } \\
\text { Ephedra foliata }\end{array}$ & $\begin{array}{l}\text { climbers in savanna } \\
\text { climbers or shrubs }\end{array}$ & $\begin{array}{l}\text { cliffs } \\
\text { shrubs }\end{array}$ & $\begin{array}{l}-\overline{-} \\
\text { aggressive climber on culti- } \\
\text { vated trees }\end{array}$ \\
\hline Pentatropis spiralis & $\begin{array}{l}\text { slender climber in sa- } \\
\text { vanna }\end{array}$ & $\begin{array}{l}\text { fleshy climber in saline } \\
\text { sink }\end{array}$ & - \\
\hline Pergularia tomentosa & small shrub & small shrub or climber & small shrub \\
\hline \multicolumn{4}{|l|}{ Grasses } \\
\hline $\begin{array}{l}\text { Pennisetum setaceum } \\
\text { Trichlolaena tenerif- } \\
\quad \text { fae }\end{array}$ & $\begin{array}{l}\text { savanna } \\
\text { sparse in savanna }\end{array}$ & $\begin{array}{l}\text { rocky cliffs } \\
\text { rocky cliffs }\end{array}$ & $\begin{array}{l}\text { ruderal } \\
\text { recently invading roadsides in } \\
\text { patches }\end{array}$ \\
\hline Aristida sieberiana & dry savanna & rocky cliffs & south-facing rocks \\
\hline Tetrapogon villosus & dry savanna & crevices in rocky cliffs & - \\
\hline
\end{tabular}

Juniperus, Colutea, Calligonum, and Haloxylon. Introduced and cultivated species were excluded as well, for example, Ficus sycamorus in Israel, and Moringa oleifera, Dalbergia sissoo, and Lawsonia inermis throughout. Such a comparison does not reveal a clear indication that the Sudanian elements in Israel show a higher proportion of species with adaptations for long-distance dispersal than those in Egypt or Sudan, although a somewhat higher percentage of Sudanian elements in Israel has adaptations for wind dispersal and exozoochory. The most striking result is that the arboreal Sudanian floras in all three areas show a very high percentage of longdistance dispersal adaptations $(61.75,70.8$, and $71.4 \%$ in Sudan, Egypt, and Israel, respectively).

On the basis of this analysis we conclude that adaptations for long-distance dispersal do not provide a clue as to the question of the age of the Sudanian flora in Israel. However, they certainly play an important role in the dispersal and survival of those elements in Israel and elsewhere in their geographical ranges.

\section{DISCUSSION}

The Sudanian assemblage of plants in Israel exhibits a typical example of the evolutionary and ecological processes that can take place in a locus terminus, where populations are small, disjunct, and vulnerable to extinction. In short, such populations face ecological and environmental conditions quite different from those in their central distribution area in Africa (Fig. 1). In the following paragraphs, we summarize the distinctive features that characterize the Sudanian elements in Israel. 


\section{ENVIRONMENTAL CONDITIONS}

The environmental conditions in which the Sudanian elements occur in Israel are generally similar to those in the main Sudanian dominion in Africa. However, there are some critical differences: in Israel there is a greater contrast between winter and summer conditions, and the overall yearly precipitation is less predictable. Moreover, the rainfall patterns are completely different. In the Sudanian region of east Africa there are two principle rainy seasons-autumn (October-November) and spring (March-April) (Lind \& Morrison, 1974), but in Israel virtually all of the rain comes in the winter (DecemberMarch) (see Fig. 10).

\section{GEOGRAPHICAL AND ECOLOGICAL SPLITTING OF THE SUDANIAN ELEMENTS}

The Sudanian elements penetrating Israel from the south split and inhabited two distinct habitats when they reached the Dead Sea Rift Valley: arboreal elements that grow in large wadis and grasses and other smaller lifeforms that tend to grow in the thermic micro-environments occurring among open rock formations.

Both a splitting of the natural Sudanian association and an intermingling of the Sudanian elements with the Saharo-Arabian and Mediterranean floras have occurred. In most places, even in the most typical "Sudanian habitats" in Israel, the Sudanian elements constitute only a small percentage of species present and are interspersed among the eremaic flora. Zohary (1962, 1973,1982 ) devoted a special geographical district to the Sudanian elements in the Arava Valley and Dead Sea area, but phytogeographical analysis of the community shows that the $\mathrm{Su}$ danian elements account for less than $15 \%$ of the total species list (see section on Distribution Patterns below). Accordingly, Feinbrun-Dothan (1985) does not recognize a Sudanian phytogeographic territory in the "Flora Palaestina." As mentioned earlier, we heartily concur with this view.

HABITAT SHIFT AMONG THE SUDANIAN ELEMENTS

Habitat shift is a phenomenon consisting of definite changes in the environmental parameters of the niche space occupied by a given species in comparison to the parameters of the niche space in another portion of the species' geographical range (MacArthur, 1968, 1972; Pianka, 1978;
Diamond, 1975). Such patterns have been frequently found in zoology (Diamond, 1975; Pianka, 1975; Krebs \& Davies, 1978) but are almost completely unnoticed in botany (see Cody \& Mooney, 1978).

Our study reveals cases of habitat shift on two geographical scales: a) the east African savannas and the Arterial Desert savannas of the Dead Sea Rift; and 2) the Dead Sea Rift and the coastal plain. Table 6 summarizes the most obvious habitat shifts displayed by the Sudanian elements under study. Most of the habitat shifts can be at least partially explained by the Eco-Geographical Rule of Boyko (1947). Since the plants in Africa are accustomed to a fairly high regime of rainfall, where they penetrate into the arid parts of Israel, they tend to be confined to habitats with improved water regimes relative to the surrounding area. Nevertheless, these specialized habitats have components that differ markedly from the African savannas even if the amount of water is approximately the same. In saline habitats, for example, the plants must contend with a high concentration of salts, whereas in rocky habitats they face a high degree of unpredictability in their water supply.

Another major habitat shift occurs in the coastal plain, where most of the Sudanian species occupy ruderal and especially segetal sites. As the cultivation of summer crops has expanded in the area over the past 100 years, certain Sudanian elements have exhibited a remarkable preadaptation to disturbed sites with artificially supplemented water in the summertime (Dafni, 1975). Some of these have become aggressive weeds throughout the coastal plain (e.g., Chrozophora tinctoria; see Table 5). Yet another case of habitat shift is displayed by those Sudanian vines that are typically climbers but in the Dead Sea Rift are restricted to cliffs and only seldomly occur on trees (e.g., Cocculus pendulus). We propose that some of the cucurbits have also undergone a habitat shift, wherein typical savanna climbers became prostrate spreading vines in the arterial wadi beds (e.g., Cucumis prophetarum, Citrullus colycynthis), but in this case the shift apparently took place at the genus level, relatively early in the evolution of the relevant sections of the family. A similar trend occurs in the Commicarpus/Boerhavia complex, in which some are climbers, some are facultative climbers (Commicarpus africanus), and some are exclusively prostrate wadi-bed vines (e.g., Commicarpus boissieri). This trend seems to represent 
a general pattern of shift of growth form concomitant with a migration from semi-desert savanna environments to extreme desert habitats.

\section{ASSOCIATION AND RE-ARRANGEMENT}

In general terms, in comparing the association of Sudanian elements in Israel with the entire association of the Sudanian flora in Africa, we find a complete lack of agreement between them. The main differences are that in Israel the Sudanian elements occur together with many species of other chorotypes and that even the details of their co-occurrence are different from those found in Africa. This pattern of non-consistent association corresponds to Gleason's (1926) individualist concept of plant geography and phytosociology, an approach that was quantitatively developed and substantiated by Whittaker (1962). Nevertheless, a small "core group" of taxa can be distinguished that are, in Israel, restricted to the Dead Sea Rift Valley. We shall call this the Arava Group (a). They are all species universally recognized as belonging to the basic Sudanian flora, which occurs continuously, if disjunctively, from dry tropical Africa to the Thar Desert. Salvadora persica, Balanites aegyptiaca, Calotropis procera, and Acacia tortilis are good examples of this group (see Figs. 4, 11).

A second group is the Fully Integrated Group (b). These are paleo-Mediterranean elements (sensu Zohary, 1973) that do not have phylogenetic allies among temperate floras but instead good, if remote, systematic links to the tropical flora. They comprise several species endemic to the Mediterranean region that currently do not occur in tropical or Sudanian regions but are replaced there by a congeneric relative (e.g., Olea europaea replaced by $O$. chrysophylla, $=O$. europaea subsp. africana) or by related genera within the same familial section or tribe (e.g., Laurus, Nerium, Phillyrea, and Tamus vis-à-vis their tropical counterparts). Zohary (1973) postulated that this group has survived since the Miocene around the Mediterranean Basin while most of the tropical elements occurring with them at that time retreated to the warmer regions of Africa (and Asia).

The Transitional Group (c) includes those species that grow in both the Dead Sea Rift and in the Mediterranean region of Israel, e.g., Ziziphus spina-christi, Demostachy bipinnata, and Hyparrhenia hirta. These species are characterized by differences in habitat in the two areas, as described earlier. In the Dead Sea Rift, they are restricted to moist habitats, i.e., salt marshes or rocky outcrops; and in the Mediterranean region, most of them are relatively widespread, especially in warm and at least slightly disturbed habitats. Indirect and published literary evidence suggests extensive invasion and expansion of these elements throughout the Mediterranean region within the last century. Yet it seems clear that the primary distribution of these species, including the now weedy grasses, is Sudanian (Eig, 1938; Zohary, 1973). For this reason we recognize them as a separate group.

In addition to the three groups described above an Anomalous Group (d) can be recognized, which includes Acacia albida and A. gerrardii subsp. negevensis. As described earlier, these two species show complex distributional and ecological patterns in Israel, the elucidation of which will require further study of the geological and paleoecological past of the area.

\section{RARITY, DISJUNCT DISTRIBUTION PATTERNS,} AND THEIR ECOLOGICAL CONSEQUENCES

Habitats in Israel where Sudanian plants dominate (Fig. 9) - rocks, cliffs, oases, and large wadis-are scattered in a topographical matrix of desert slopes that do not permit the existence of non-xeric plants. Consequently, most populations of these Sudanian species in Israel are small and disjunct.

In many rocky habitats in the Dead Sea area and along the Arava Valley, common desert species (Saharo-Arabian elements) are found instead of Sudanian species. The absence of Sudanian elements in these apparently suitable sites is probably due to high rates of local extinction (cf. Stebbins, 1952) and rare recolonization events.

\section{THE AGE OF THE SUDANIAN ELEMENTS IN THE FLORA OF ISRAEL}

Points in favor of the antiquity of Sudanian vegetation in the study area are the following:

1. Strong paleontological evidence exists for the gradual decrease (attenuation) of tropical animals in the area from the Miocene to the Holocene (Tchernov, 1968, 1975).

2. The "paleomediterranean elements" (sensu Zohary, 1973) of Israel show a distinctly relict distribution pattern with secondary adaptations to the Mediterranean area. Examples are 
Olea europaea and Ceratonia siliqua, both of which are present-day components of the evergreen maquis that have decidedly tropical affinities.

3. The random and disjunct character of many Sudanian species growing in oases and by springs in cliffs and gorges might suggest that the vegetation is relict in character (Zohary, 1962, 1973). According to this theory, the vegetation that once covered the whole area contracted to moister habitats as the climate grew dryer.

Points in favor of the recency of most of the Sudanian vegetation in the study area are:

1. Cold conditions in the Pliocene and the glacial periods of the Pleistocene were unfavorable to Sudanian vegetation existing in the study area, which was consequently destroyed after the Miocene (Galil, 1972).

2. Up to the Pleistocene the Dead Sea Rift was apparently only a shallow depression, in which a pseudo-Sudanian climate appropriate for thermophilic Sudanian species could not exist. During the last glacial period the central Dead Sea Valley was covered by the Lisan Lake and the climate was cooler (Neev \& Emory, 1967; Horowitz, 1979) and therefore not appropriate for the existence of the xerophytic Sudanian species growing there today.

3. Most Sudanian species in Israel have undergone virtually no speciation relative to their larger populations in east Africa. Those taxa that have speciated have done so to a very low degree (variety or subspecies level). In most species with endemic taxa, gradual morphological transitions can be found between the endemic taxa and the corresponding Sudanian sibling species.

4. Many Sudanian species have efficient longdistance dispersal mechanisms and could have reached the disjunct habitats suitable for their growth by this method (see previous section on Long-Range Dispersal). In light of recent research on the seed dispersal ability of many plants occurring on oceanic islands (Carlquist, 1974), this evidence seems significant.

5. The disjunct and apparently random distribution of Sudanian vegetation in the Dead Sea Rift can be attributed not only to their being relicts from a different climatic period, but also to long-distance dispersal and the scarcity of appropriate habitats. According to this view, many habitats suitable for the existence of Sudanian vegetation can be expected to remain empty or populated by only one species (cf. Ellner \& Shmida, 1981). What seems to be a random pattern at the single species level can be explained by consistent statistical evidence at the community and total Sudanian flora level (see Ellner \& Shmida, 1981).

6. That the indisputably relict "paleomediterranean elements" occur entirely in the Mediterranean region of Israel and not in the Dead Sea Rift is further evidence that relicts and recent arrivals show divergent distribution patterns in the study area. The unique distribution of Acacia gerrardi subsp. negevensis also stands in marked contrast to that of the remainder of the Sudanian elements in the area. The former shows a clearly relict pattern while the latter do not.

7. The existence of a transitional group and a wide range of marked habitat shifts (see previous sections) in the Sudanian elements occurring in Israel outside of the Dead Sea Rift also argues for the recency of the Sudanian flora as a whole in the area. Invasion and penetration of these elements can be seen taking place at a rapid rate in localities characterized by human disturbance.

8. Very few endemic species are found in the Dead Sea Rift where the great majority of Sudanian floral and faunal elements in Israel occur. The only clear exceptions are the boraginaceous chamaephyte Trichodesma boissieri and the sunbird, Cinnyris osea, both of whose nearest systematic relatives occur in east Africa, over $1,000 \mathrm{~km}$ away. In the Mediterranean region, one paleoendemic Sudanian butterfly exists, namely Caharexes jasius (Larsen, 1974). By contrast, in both the IranoTuranian and the Mediterranean elements of the Israeli flora, a large number of endemics or sub-endemics exist. Many of these occupy rocky or otherwise locally isolated habitats. Similar habitats supporting Sudanian elements, although many hundreds of kilometers away from their nearest congeneric neighbors, are nevertheless devoid of paleoendemics.

\section{Conclusions}

In our opinion, the large majority of the Sudanian plant species occurring in the Negev and 
Dead Sea Rift Valley today are of recent origin and have reached the area only after the last glacial period. That is, most of the Sudanian species presently occurring in Israel, with the exception of Trichodesma boissieri and Acacia gerrardi subsp. negevensis, started to penetrate from the south about 12,000 to 17,000 years ago. This process continued throughout the Holocene. This conclusion does not exclude the possibility that Sudanian elements, including some of the same species found here today, existed in Israel in more ancient times during the Pleistocene and late Tertiary. Nevertheless, the existence of Tertiary tropical flora in Israel has yet to be proved by fossils. By contrast, evidence for tropical fauna during the early Pleistocene is plentiful, mainly from the fossils found at Ubediyah of the elephant, giraffe, and hippopotamus (Tchernov, 1975; Bar Yosef \& Tchernov, 1972).

It is interesting to note that analogous questions concerning the age of a northern tongue of penetration of the Mediterranean Arbutus group were investigated by Sealy (1949). The occurrence of Arbutus unedo in habitats edaphically unsuitable for woodland in a few sites in Brittany and western Ireland, surrounded by plants of very different overall chorotypes, was investigated from a variety of angles. Rejecting the argument of an ancient relict situation for this Mediterranean element far from its main phytogeographical region, Sealy concluded that Arbutus unedo had invaded these isolated habitats only recently, for reasons very similar to those favored by us concerning the Sudanian elements in Israel.

Kosswing (1955) analyzed the biogeography of tropical elements in Turkey and concluded that some of the Sudanian elements are ancient (20 million years or more) while others are recent (hundreds of thousands of years). The same is true of the Sudanian elements in Israel, according to the opinion held by most biogeographers in Israel today (Galil, 1972; Heller, pers. comm.; Lipkin, pers. comm.; Tchernov, pers. comm.). The question now is the size and importance of the patterns, speciation level, and phylogenetic relationships of Sudanian vegetation. We conclude that in the Negev and Dead Sea Rift Valley the overwhelming majority of Sudanian elements are very recent. They penetrated the area primarily along the Syrian-African Rift during the various inter-glacial periods. Most of the extant Sudanian vegetation probably reached the area only at the end of the upper Pleistocene and during the Holocene, after the Lisan Lake dried up and the rapid deepening of the Rift took place. On the other hand, a significant portion of the species with tropical affinities occurring in the Mediterranean area of Israel are probably ancient and can be considered Miocene relicts, both from their geographical disjunction and systematic isolation (Zohary, 1973).

\section{Literature Cited}

Aaronsohn, A. 1913. Notules de phytogeographie palestinne (I). Une station peu connue de l'Acacia albida Del. Bull. Soc. Bot. France 60: 495-502.

Aloni, R.\& G. Orshan. 1972. The vegetation of the Lower Galilee, Israel. Israel J. Bot. 21: 209-227.

Andrews, F. W. 1950-1956. The Flowering Plants of the Anglo-Egyptian Sudan, 3 volumes. Sudan Government by T. Bunck, Arbroath, Scotland.

ANonymous. 1970. Atlas of Israel. 2nd edition. Department of Surveys, Ministry of Labor, Jerusalem.

AXELROD, D. 1975. Evolution and biogeography of the Madrean-Tethyan sclerophyll vegetation. Ann. Missouri Bot. Gard. 62: 280-334.

\& P. H. RAVEN. 1978. Late Cretaceous and Tertiary vegetation history of Africa. Pp. 99-130 in M. J. A. Werger (editor), Biogeography and Ecology of Southern Africa. W. Junk, The Hague.

Bar Yosef, O. 1975. The Epi-Paleolithic in Palaestine and Sinai. Pp. 363-378 in F. Wendorf \& A. Marks (editors), Problems in Pre-history: North Africa and the Levant. Southern Methodist Univ., Dallas.

\& E. TChernov. 1972. On the Paleo-ecological History of the Site of Ubeidiya. Israel Academy of Science and Humanities, Jerusalem.

Bhandari, M. M. 1978. Flora of the Indian Desert. Scientific Publishers, Jodhpur.

Bodenheimer, F. S. 1935. Animal Life in Palestine. L. Mays, Jerusalem.

Boros, I. \& L. HORVATH. 1954. The distribution of Passer moabiticus. Acta Zool. 1(1-2): 43-51.

Boulos, L. 1962. Cytotaxonomic studies in the genus Sonchus. 4. The generic status of some species earlier treated as Sonchus. Bot. Not. 115: 58-60.

BоYко, H. 1947. On the role of plants as quantitative climatic indicators and the geo-ecological law of distribution. J. Ecol. 35: 138-157.

BURTT, B. L. 1971. From the south: an African view of the floras of western Asia. Pp. 135-154 in P. H. Davis, P. C. Harper \& I. C. Hedge (editors), Plant-Life in South-West Asia. Botanical Society of Edinburgh, Edinburgh.

CARLQUIST, S. 1974. Island Biology. Columbia Univ. Press, New York.

Chevalier, A. 1934. Nouvelles observations sur quelques Acacia de l'Afrique. Rev. Bot. Appl. Agric. Trop. 14: 875-884.

- 1938. Le Sahara, Centre d'Origine des Plantes Cultivées. In L. Aufrere et al., La Vie dans la Region Désertique Nord-Tropicale de l'Ancien Monde. Mém Soc. Biogéogr. 6: 307-322.

CODY, M. L. \& H. A. MoONEY. 1978. Convergence 
versus nonconvergence in Mediterranean-climate ecosystems. Annual Rev. Ecol. Syst. 9: 265-321.

DAFNi, A. 1975. Comparative biology of Prosopis farcta in four different habitats in Israel. Ph.D. thesis. Hebrew Univ., Jerusalem. [In Hebrew with English summary.]

Danin, A. 1983. Desert Vegetation of Israel and Sinai. Cana, Jerusalem.

Davis, P. H. \& V. H. HeYwood. 1963. Principles of Angiosperm Taxonomy. Oliver \& Boyd, Edinburgh.

DiAmond, J. M. 1975. Assembly of species communities. Pp. 342-444 in M. L. Cody \& J. M. Diamond (editors), Ecology and Evolution of Communities. Belknap, Cambridge, Massachusetts.

EIG, A. 1931-1932. Les éléments et les groupes phytogéographiques auxiliares dans la flore palestinienne. Feddes Repert. Spec. Nov. Regni Veg. 63(1): 1-201 [text, 1931]; 63(2): 1-120 [analytical tables, 1932].

_. 1938. On the phytogeographical subdivision of Palestine. Palestine J. Bot., Jerusalem Ser. 1: 412.

12. 1946. Synopsis of the phytosociological units of Palestine. Palestine J. Bot., Jerusalem Ser. 3: 183-246.

EllNER, S. \& A. SHMIDA. 1981. Why are adaptations for long-range seed dispersal rare in desert plants? Oecologia 51: 133-144.

ENGLER, A. 1879-1882. Versuch einer Entwicklungsgeschichte der Pflanzenwelt insbesondere der Florengebiete seit der Tertiärperiode, 2 volumes. Engelmann, Leipzig.

\& O. DRUDE (editors). 1896. Die Vegetation der Erde. Engelmann, Leipzig.

Evenari, M., L. Shannon \& N. Tadmor. 1982. The Negev: The Challenge of a Desert, 2nd edition. Harvard Univ. Press, Cambridge.

Feinbrun-Dothan, N. 1978. Flora Palestina. Part 3. Israel Academy of Sciences and Humanities, Jerusalem.

—. 1985. Flora Palestina. Part 4. Israel Academy of Sciences and Humanities, Jerusalem.

FREUND, R. 1965. A model of the structural development of Israel and adjacent areas since Upper Cretaceous times. Geol. Mag. 102: 189-205.

- \& Z. Garfunkel. 1978. Guidebook to Excursions Along the Dead Sea Rift. Department of Geology, Hebrew Univ., Jerusalem.

, I. ZAK \& Z. GARFunKEL. 1968. Age and rate of sinistral movement along the Dead Sea Rift. Nature 220: 253-255.

, Z. Garfunkel, I. ZaK, M. GoldberG, T. Weissbrod \& B. Perin. 1970. The shear along the Dead Sea Rift. Philos. Trans., Ser. B, 267A: 107-130.

GaLIL, J. 1972. The origin of the Sudanian vegetation in Israel. Tev' Va'Arets 14(4): 139-145. [In Hebrew.]

Garfunkel, Z. 1970. The tectonics of the western margins of the Southern Arava. Unpubl. Ph.D. thesis. Hebrew Univ., Jerusalem. [In Hebrew.]

\& A. HoRowirz. 1966. The upper Tertiary and Quaternary morphology of the Negev. Israel J. Earth Sci. 15: 101-117.
Gleason, H. 1926. The individualistic concept of the plant association. Bull. Torrey Bot. Club 53: $7-26$.

Goon, R. 1964. The Geography of the Flowering Plants. Longman, London.

GreEnway, P. J. 1970. A classification of the vegetation of East Africa. Kirkia 9: 1-68.

GrisebACH, A. 1884. Die Vegetation der Erde nach ihrer klimatische Anordung, 2 volumes. W. Engelmann, Leipzig.

Gruenberg-Fertig, I. 1954. On the "Sudano-Deccanian" elements in the flora of Palaestine. Palestine J. Bot., Jerusalem Ser. 6: 234-240.

Halevy, G. 1970. Distribution of Acacia gerrardii subsp. negevensis and the Geologic past. Tev' Va'Arets 12(5): 209-212. [In Hebrew with English summary.]

- 1971. A study of Acacia albida in Israel. LaYa'aran 21: 52-63. [In Hebrew with English summary.]

— \& G. ORSHAN. 1972. Ecological studies on Acacia species in the Negev and Sinai. I. Distribution of Acacia raddiana, $A$. tortilis and $A$. gerrardii subsp. negevensis. Israel J. Bot. 22: 120138.

Hamilton, C. A. 1982. Environmental History of East Africa. Academic Press, London.

HART, H. C. 1891. Some Accounts of the Fauna and Flora of Sinai, Petra and Wâdy Arabah. Committee of the Palestine Exploration Fund, London.

Hedge, I. C. \& P. Wendelbro. 1978. Patterns of distribution and endemism in Iran. Notes Roy. Bot. Gard., Edinburgh 36: 441-464.

Hillcoat, D., G. Lewis \& B. Verdcourt. 1980. A new species of Ceratonia (Leguminosae-Cesalpinoideae) from Arabia and the Somali Republic. Kew Bull. 35: 260-271.

Horowitz, A. 1979. The Quaternary in Israel. John Wiley, New York.

KARSCHON, R. 1961. Acacia albida Del. in Israel and the Near East. La-Ya'aran 1 1(2): 4-6. [In Hebrew with English summary.]

Kerauden, M. 1965. Le genre Moringa en Afrique et a Madagascar. Webbia 19: 815-824.

KNAPP, R. 1973. Die Vegetation von Africa. Fischer, Stuttgart.

Kosswing, C. 1955. Zoogeography of the Near East. Syst. Zool. 4: 49-74.

Krebs, J. R. \& N. B. Davies (editors). 1978. Behavioral Ecology: An Evolutionary Approach. Blackwell Scientific Publ., Oxford.

Kumerlove, H. 1971. The Dead Sea sparrow: a second breeding place on Turkish and first known breeding place on Syrian territory. Ibis 3: 617618.

LARSEN, T. R. 1974. Butterflies of Lebanon. National Council for Scientific Research, Beirut.

Le Houerou, H. \& G. F. Popov. 1981. An eco-climatic classification of intertropical Africa. FAO Pl. Protect. Bull. 31: 1-40.

LIND, E. M. \& M. E. S. Morrison. 1974. East African Vegetation. Longman, London.

Litav, M. 1967. Micro-environmental factors and species interrelationships in three Batha associations in the foothill region of the Judean Hills. Israel J. Bot. 16: 79-99. 
LORCH, J. 1966. A Pleistocene florule from the Central Jordan Valley. Israel J. Bot. 15: 31-34.

MacArthur, R. H. 1968. The theory of the niche. Pp. 159-186 in R. C. Lewontin (editor), Population Biology and Evolution. Syracuse Univ., Syracuse.

- 1972. Geographical Ecology. Harper \& Row, New York.

Mandaville, J.P. 1984. Studies in the flora of Arabia XI: some historical and geographical aspects of a principal floristic frontier. Notes Roy. Bot. Gard. Edinburgh 42: 1-15.

MAYr, E. 1970. Animal Species and Evolution. Harvard Univ, Press, Cambridge.

Meyer-Homji, V. M. 1965. On the 'Sudano-Deccanian' floral element. J. Bombay Nat. Hist. Soc. 62: $15-18$.

MONOD, T. 1957. Les grandes divisions chorologiques de l'Afrique. Publ. Cons. Sci. Afrique Sud Sahara 24: 1-146.

Neev, D. \& D. O. Emory. 1967. The Dead Sea depositional processes and environments of evaporites. Bull. Geol. Surv. Israel 41: 1-147.

NiR, D. \& O. BAR YoSef. 1976. Quaternary Environment and Man in Israel. Israel Nature Protection Society, Tel Aviv.

OzENDA, P. 1977. Flore du Sahara, 2nd edition. CNRS, Paris.

Pelssier, P. 1977. Competition and the integration of agriculture and cattle raising in Sahelien and Soudano-Sahelien Africa. In Proceedings of the International Symposium on Rainfed Agriculture in Semi-Arid Regions. Univ. of California, Riverside.

PIANKA, E. R. 1975. Niche relations of desert lizards. Pp. 292-314 in M. L. Cody \& J. M. Diamond (editors), Ecology and Evolution of Communities. Harvard Univ. Press, Cambridge.

—. 1978. Evolutionary Ecology, 2nd edition. Harper \& Row, New York.

Quézel, P. 1958. Mission Botanique au Tibesti. Mem. Inst. Rech. Sahariennes 4: 1-357.

1965. La Vegetation du Sahara. Fischer, Stuttgart.

- 1978. Analysis of the flora of Mediterranean and Saharan Africa. Ann. Missouri Bot. Gard. 65: 479-534.

RadWANSKi, S. A. \& G. E. Wickens. 1967. The ecology of Acacia albida on mantle soils in Zalingei, Jebel Marra, Sudan. J. Appl. Ecol. 4: 569-579.

Raven, P. H. 1977. The California flora. Pp. 109137 in M. Barbour \& J. Major (editors), Terrestrial Vegetation of California. Wiley \& Sons, New York.

Reveal, J. L. 1976. Dedeckera (Polygonaceae), a new genus from California. Brittonia 28: 245-251.

Ross, J. H. 1966. Acacia albida in Africa. Bol. Soc. Brot., Ser. 2, 40: 187-205.

- 1979. A conspectus of the African Acacia species. Mem. Bot. Surv. South Africa 44: 1-155.

1981. A biogeographical analysis of the African Acacia species. Bothalia 13: 389-402.

SeAly, J. R. 1949. Arbutus unedo. J. Ecol. 37: 365388.

ShmidA, A. 1982. Mediterranean vegetation in California and Israel: similarities and differences. Israel J. Bot. 30: 105-123.
1985. Biogeography of the desert floras of the world. In M. Evenari \& I. Noy-Meir (editors), Hot Desert Ecosystems of the World, Volume 12. Elsevier, New York.

- \&S. ElLNER. 1985. Coexistence of plant species with similar niches. Vegetatio 54: 29-55.

SNEH, A. \& T. Weissbrod. 1973. Nile Delta: the defunct Pelusic Branch identified. Science 180: 5962.

Stebrins, G. L. 1952. Aridity as a stimulus to plant evolution. Amer. Naturalist 86: 33-44.

1971. Relationships between adaptive radiation, speciation and major evolutionary trends. Taxon 20: 3-16.

-1972. Ecological distribution of centers of major adaptive radiation in angiosperms, II. Seeds and seedlings. Pp. 7-34 in D. Valentine (editor), Taxonomy, Phytogeography and Evolution. Academic Press, New York.

TÄCKHOLM, V. 1974. Students' Flora of Egypt, 2nd edition. Cairo Univ., Beirut.

Takhtajan, A. 1969. Flowering Plants: Origin and Dispersal. Oliver \& Boyd, Edinburgh.

TCHERNOV, E. 1968. Succession of Rodent Fauna During the Upper Pleistocene of Israel: Mammalia Depicta. Paul Paney, Hamburg.

- 1975. The Early Pleistocene Molluscs of Erq el-Ahmar. Israel Academy of Sciences and $\mathrm{Hu}-$ manities, Jerusalem.

TristraM, H. B. 1884. The Survey of Western Palestine: The Fauna and Flora of Palestine. Committee of the Palestine Exploration Fund, London.

UDVARDY, M. D. 1969. Dynamic Zoogeography. Van Nostrand Reinhold, New York.

WALTER, H. 1979. Vegetation of the Earth, 3rd edition. Springer, New York.

WERGER, M. J. A. 1973. Notes on the phytogeographical affinities of the southern Kalahari. Bothalia 11: $177-180$.

. 1978. Biogeographical division of Southern Africa. Pp. 145-169 in M. J. A. Werger (editor), Biogeography and Ecology of Southern Africa. W. Junk, The Hague.

\& B. J. Coetzee. 1978. The Sudano-Zambezian Region. Pp. 193-224 in M. J. A. Werger (editor), Biogeography and Ecology of Southern Africa. W. Junk, The Hague.

White, F. 1967. The savanna woodlands of the Zambezian and the Sudanian domains: an ecological and a phytogeographical comparison. Webbia 19: $651-671$.

- 1983. The Vegetation of Africa. Unesco, Paris.

WhitTAKeR, R. H. 1962. Classification of natural communities. Bot. Rev. (Lancaster) 28: 1-239.

1977. Evolution of species diversity in land communities. Evol. Biol. 10: 1-65.

- , L. E. Gilbert \& J. H. Connell. 1979. Analysis of two-phase pattern in a mesquite grassland, Texas. J. Ecol. 67: 935-952.

Wickens, G. E. 1968. Some additions and corrections to F. W. Andrew's Flowering Plants of the Sudan. Forests Bull. Forests Dept., Sudan n.s. 14: $1-64$.

1969. A study of Acacia albida Del. (Mimosoideae). Kew Bull. 23: 181-202.

1976. The flora of Jebel Marra (Sudan Re- 
public) and its geographical affinities. Kew Bull. Add. Ser. 5: 1-368.

Zohary, D. \& P. SPIEgEL-RoY. 1975. Beginnings of fruit-growing in the Old World. Science 187: 319 327.

ZOHARY, M. 1945. Outline of the vegetation in Wadi Araba. J. Ecol. 32: 204-213.

1955. Geobotany. Sifriat Poalim, Merhavia. [In Hebrew.]

1962. Plant Life of Palestine: Israel and Jordan. Ronald Press, New York.

. 1963. On the geo-botanical structure of Iran. Bull. Res. Council Israel, Sect. D, Bot. 11 (Suppl.): 1-113.
1973. Geobotanical Foundations of the Middle East. 2 parts. Springer, Berlin.

. 1982. Plants of the Bible. Cambridge Univ. Press, Cambridge.

\& N. Feinbrun-Dothan. 1966-1974. Flora Palestina. Parts 1 and 2. Israel Academy of Sciences and Humanities, Jerusalem.

\& G. OrShan. 1956. Ecological studies in the vegetation of the Near East Deserts. II. Wadi Araba. Vegetatio 7: 15-37.

\& G. OrShaNSKY. 1949. Structure and ecology of the vegetation in the Dead Sea Region of Palestine. Palestine J. Bot., Jerusalem Ser. 4: 177206. 